\title{
The Effect of Low-Wage Import Competition on U.S. Inflationary Pressure
}

Raphael Auer and Andreas M. Fischer

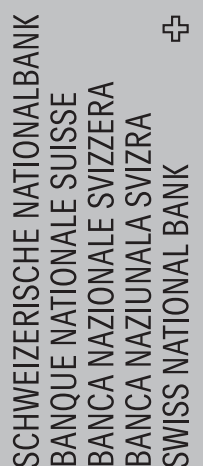

น

(1)

0

ro

ค

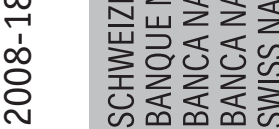


The views expressed in this paper are those of the author(s) and do not necessarily represent those of the Swiss National Bank. Working Papers describe research in progress. Their aim is to elicit comments and to further debate.

ISSN 1660-7716 (printed version)

ISSN 1660-7724 (online version)

๑ 2008 by Swiss National Bank, Börsenstrasse 15, P.0. Box, CH-8022 Zurich 


\title{
The Effect of Low-Wage Import Competition on U.S.
}

\section{Inflationary Pressure*}

\author{
Raphael AuER and Andreas M. Fischer \\ Swiss National Bank/Swiss National Bank and CEPR
}

December 11, 2008

\begin{abstract}
This paper develops a new methodology to estimate the effect of low-wage import competition on U.S. producer prices. We first document that when low-wage countries grow, their exports to the United States increase most in labor-intensive sectors. Second, we demonstrate that the temporary and relative component of imports induced by labor intensity and output growth in low-wage countries is orthogonal to U.S. supply and demand shocks and can, therefore, be utilized to identify the causal impact of import competition on prices. In a panel covering 325 manufacturing industries from 1997 to 2006, we find that imports from nine low-wage countries are associated with strong downward pressure on U.S. prices. When these nations capture $1 \%$ U.S. market share, producer prices decrease by $3.1 \%$, which is nearly fully accounted by a $2.4 \%$ increase in labor productivity and a $0.4 \%$ decrease in markups. Overall, we find that imports from the examined countries have decreased U.S. manufacturing PPI inflation by around two percentage points each year.
\end{abstract}

Keywords: Low-Wage Country Import Competition, Comparative Advantage, Globalization JEL: F14, F15, and F16

*Email: raphael.auer@snb.ch (corresponding author) and andreas.fischer@snb.ch. The authors would like to thank Domagoj Arapovic, Richard Baldwin, Thomas Chaney, Pushan Dutt, Robert Feenstra, Jean Imbs, Enrique Martinez-Garcia, Philip Saure, Ákos Valentinyi, Mark A. Wynne, an anonymous referee at the SNB Working Paper Series, and seminar participants at the Swiss National Bank, the Austrian National Bank, MNB/ CEU, the 2008 annual meeting of the European Economic Association, and the CEPR/MNB Workshop on Trade, Productivity, and Development for helpful comments and discussions; and Domagoj Arapovic for excellent research assistance. The views expressed in this paper do not necessarily represent those of the Swiss National Bank. 
Have cheap imports from low-income, low-wage nations held down inflationary pressure in rich economies? Contrary to what customers at Wal-Mart, Toys"R"Us, or Best Buy observe every day, the academic literature has found surprisingly little evidence that trade with China and other poor, yet rapidly industrializing nations, has had a large impact on prices in the rest of the world.

Due to the paucity of one-time tariff reductions that could be utilized to establish the impact of low-wage country (LWC) import competition, a large part of the current literature relies on ordinary least squares (OLS) estimates. ${ }^{1}$ For example, studies by Ball (2006), Feyzioglu and Willard (2008), Gamber and Hung (2001), Ihrig et al. (2007), Kamin et al. (2006), Pain et al. (2006), or Tootell (1998) evaluating the effect of low-wage imports on U.S. prices cannot disentangle U.S. demand shocks from supply shocks abroad and, therefore, cannot identify the effect of import competition on inflationary pressure in the United States. ${ }^{2}$

This paper is the first study identifying the causal effect of import competition from the major low-wage economies on inflationary pressure in the U.S. A wide literature, including Trefler (1993 and 1995), Davis and Weinstein (2001), Romalis (2004), and Chor (2008), has documented that labor abundant countries have a comparative advantage in labor intensive sectors. The starting observation of this paper is that the relation between comparative advantage and imports also holds at the margin: if the aggregate industrial output of a LWC grows, exports to the United States increase much more in labor intensive sectors than in capital intensive sectors. Below, we show how these marginal trade flows induced by comparative advantage can identify the effect of LWC imports on U.S. industry.

Our study draws upon the work of Bernard et al. (2006), who utilize variation in sectoral import shares to identify the effect of low-wage import competition on U.S. firm entry and exit dynamics. As these authors are well aware, sectoral import shares themselves are endogenous to U.S. demand and they, therefore, use ad valorem tariffs, freight rates, and lagged import

\footnotetext{
${ }^{1}$ We are not aware of one-time events that induced a sizeable increase in imports from these nations. For example, China's accession to the WTO in 2001 reduced average tariffs by less than two percentage points. Although the accession of Mexico to NAFTA had a sizeable effect on Mexico (see Hanson (2003)), the increase of Mexican imports did not affect the United States to an extent measurable in nationwide data.

${ }^{2}$ Studies focusing on inflation that find a muted or no effect of LWC import competition - including Ball (2006), Ihrig et al. (2007), Pain et al. (2006), and Tootell (1998) - use conventional specifications of the Phillips curve to determine the role of foreign output gaps or import prices on domestic inflation. Feyzioglu and Willard (2008), Gamber and Hung (2001), and Kamin et al. (2006) focus on the effect of the share of imports originating from LWCs on inflationary pressure.
} 
shares to instrument for these trade flows. A related strategy has been employed by Chen et al. (2007), who identify the pro-competitive effect of trade within a set of eight European nations. The latter authors instrument for trade with transportation costs, Hummels' (2001) measure of good bulkiness, and a measure of the geographic potential for trade derived from a gravity-type equation. ${ }^{3}$

The main novelty of our empirical strategy is to construct an instrument for trade that is directly based on comparative advantage. The obvious motive of doing so is that comparative advantage can explain a large fraction of trade between nations at different stages of development, such as the United States and the newly industrialized world. This is especially important since our analysis is in first differences: while the instruments used in the current literature display little variation over time, the instrumentation strategy of this paper can also predict marginal trade flows at very high levels of significance.

More importantly, as demonstrated by Bernard et al. (2007), trade motivated by comparative advantage has macroeconomic implications different from the ones when trade is induced by motives such as transportation costs. We believe that researchers and policy makers alike are primarily interested in understanding to what extent low wages in China and the other emerging economies have translated into lower U.S. prices of labor intensive imports and, consequently, into lower U.S. inflationary pressure. Since we isolate exclusively the component of trade that is motivated by low wages, our strategy is well-suited to analyze the impact of low-wage import competition on U.S. prices.

Our analysis proceeds in three stages. In the first part, we describe the evolution of imports from nine low-wage economies from 1997 to 2006. The comparative advantage of these nations is in labor intensive sectors. The composition of imports has remained remarkably stable over the last decade, while trade volume grew strongly. Consequently, U.S. import competition has increased mostly in labor intensive sectors. We then show that the relative increase of import competition in labor intensive sectors was most pronounced in the years when the growth of industrial output in the emerging economies was highest. More specifically, we document that the

\footnotetext{
${ }^{3}$ Glatzer et al (2006), $\operatorname{IMF}(2006)$, and Wheeler (2008) apply the empricial strategy by Chen et al. (2007) for Austria, OECD countries, and the United Kingdom, respectively.
} 
interaction of a sector's labor intensity and the growth rate of industrial output in the examined economies can predict changes in U.S. import competition. We refer to the component of trade that can be explained by this interaction as the "comparative advantage-induced" trade flows.

In the second part of the analysis, we develop an empirical framework to identify how comparative advantage-induced trade flows have affected prices in the United States. Our analysis includes fixed effects by sectors and year dummies. Since the analysis below is in first differences, all sector-specific structural trends in prices or import volumes are thus captured in the sector dummies. Due to the additional presence of year dummies, all shocks we identify are relative shocks, i.e., we relate relative changes in import competition to changes in relative prices.

Before turning to our results, we test whether our strategy is well-suited to examine the causal impact of import competiton. A potential concern with our analysis is that even temporary U.S. shifts into capital intensive sectors could result in both increasing imports concentrated in labor intensive sectors and aggregate output growth in low-wage economies. While we do not observe U.S. demand and supply shocks directly, these alter the level of U.S. consumption, U.S. production, and U.S. non-LWC imports, which are all observable. We thus demonstrate that the relative and temporary component of comparative advantage-induced trade flows is orthogonal to structural shifts in the United States. We also highlight the large potential bias in OLS estimates.

In the third part of the analysis, we present the results of this study. Low-wage import competition has had a profound impact on U.S. relative producer prices. ${ }^{4}$ The two-stage least squares estimates reveal a strong negative relationship between changes in LWC import share and changes in U.S. producer prices. We find that when our nine LWCs capture 1\% market share in a sector, U.S. producer prices decrease between $2 \%$ and $3 \%$. This result stands in stark contrast to OLS estimates predicting an insignificant and often positive correlation between these two variables.

We next decompose the price-dampening effect into the contribution of labor productivity growth, markup reductions, and input cost fluctuations. Surprisingly, we find that the dominant channel through which LWCs have affected U.S. industry is by inducing sectoral productivity

\footnotetext{
${ }^{4}$ We do not analyze the direct effect of changes in import competition on U.S. import prices since the latter are not available on a bilateral basis and, furthermore, aggregate import price data are available only for a small number of sectors.
} 
growth, as predicted by Melitz (2003) and, in particular, Bernard et al. (2007). In our estimations, a one percentage-point increase in the U.S. market share of LWC imports is associated with an increase of labor productivity of about two percentage points. Further corroborating the evidence in favor of the "new" new theories of trade, we also document that the response of prices and productivity to import competition is systematically related to the elasticity of demand. While the response of import flows to growth in LWCs is much more pronounced in sectors with elastic demand, the response of prices and productivity to a given increase of import competition is higher in sectors with inelastic demand.

We next analyze whether LWC import competition has affected the cost of production. We do not find any evidence of a negative effect of LWCs on the wages of unskilled workers. However, given the difference-in-difference setup, our approach can only detect whether import competition causes sectoral variation in wages, yet not whether import competition in general has depressed wages. Last, we investigate whether low-cost intermediate goods lower U.S. prices relying on the measure of input intensity developed by Schott (2004). We do not find that cheap imported input goods can explain lower U.S. prices.

The conclusion of this paper is that globalization has had a profound impact on U.S. relative prices and productivity, much larger than is commonly assumed. Our results, however, should be interpreted with care when making statements about the aggregate effect of LWCs on U.S. inflationary pressure. We estimate the effect on relative prices, and due to the difference-indifference type identification, our methodology abstracts from factors such as the increase in global raw material prices that growth in LWCs has brought about or the optimal response of central banks to relative price shocks. Given these limitations, a rough estimate is that from 1997 to 2006, the U.S. PPI inflation rate in the manufacturing sector was reduced due to the trade with LWCs by about two percentage points each year, while productivity growth was increased by one to two percentage points in the sectors examined in this paper. China accounts for over one half of the total effect.

The paper is organized as follows. Section 1 describes the data, the evolution of low-wage import competition over time, and documents that marginal imports from LWCs can be explained by comparative advantage. Section 2 lays down the empirical framework and discusses 
the identifying assumption. Section 3 presents the empirical results. Section 4 decomposes the price change into the contributions of productivity growth, markup declines, and costs reductions. Section 5 analyses the impact of the elasticity of demand on the response of U.S. prices on import competition. Section 6 concludes.

\section{Comparative Advantage and the Evolution of LWC Imports}

In this section, we describe the evolution of U.S. imports from China, Brazil, Indonesia, India, Malaysia, Mexico, the Philippines, Thailand, and Vietnam. ${ }^{5}$ While the overall volume of imports from these nations grew substantially over the last decade, the composition of these imports has been fairly stable over this period. We next document that static comparative advantage and the growth rate of industrial output in LWCs can explain marginal trade flows, i.e., changes in import competition.

\subsection{Data Description}

We use sectoral and annual trade data from the United States International Trade Commission (USITC), covering the 1997-2006 period. The classification of the import data is 6-digit North American Industry Classification System (NAICS) and the selected trade type is the General Customs value. ${ }^{6}$ U.S. data on wages, producer prices, and productivity (4- to 6-digits) are from the Bureau of Labor Statistics (BLS). ${ }^{7}$ Information to construct sectoral markups were taken from the Annual Survey of Manufactures, see Appendix A for the respective definition of variables. The overlap of industry information from the Annual Survey of Manufacturers and the price data from the BLS yields 325 different sectors (NAICS codes 311111 to 339999$)$.

Our measure of import penetration is constructed in the following way.

Definition 1 (Low-Wage Import Competition). Denote low-wage import competition in sector $j$

\footnotetext{
${ }^{5}$ Appendix C explains our sampling criterion in selecting these nine LWCs.

${ }^{6}$ The General Customs value is appraised by the U.S. Customs Service and is the price paid or payable for merchandise when sold for exportation, excluding U.S. import duties, freight, insurance, and other changes incurred. ${ }^{7}$ The BLS publishes only 4-digit data on its website. Additional data were obtained through private correspondence.
} 
at time $t$ by $m_{l w c, j, t}$. The variable, $m_{l w c, j, t}$ is defined as follows

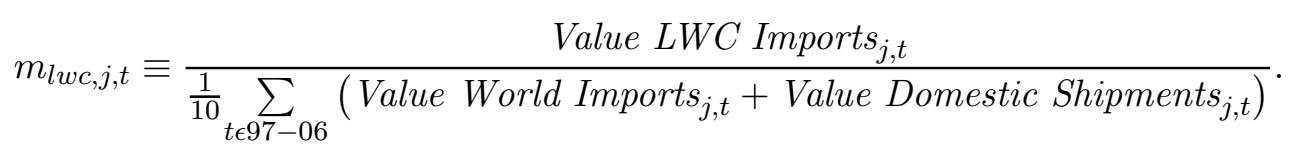

We follow Bernard et al. (2006) in defining low-wage import competition as the expenditure share of imports from the nine LWCs divided by total U.S. sales. U.S. sales equal the sum of world imports plus domestic shipments. To make sure that our results are not driven by the endogenous response of U.S. sales to U.S. demand, the value of domestic shipments plus world imports is averaged over the 10 years in our sample. ${ }^{8}$ Our measure of import penetration takes the value of 0.01 in a sector where imports from the country in question amount to $1 \%$ of average U.S. sales in the respective sector.

In most of the analysis below, we evaluate absolute changes in import penetration. All changes in variables are denoted by $\Delta$, i.e., $\Delta m_{l w c, j, t}=m_{l w c, j, t}-m_{l w c, j, t-1}$. This strategy is expedient since the response of U.S. prices should be related to the increase of imports normalized by U.S. demand rather than related to the percentage increase of imports. Further, evaluating absolute growth rather than the relative (percentage) growth of imports does not force us to drop any zero-trade observations.

To measure an industry's labor intensity, we use information from the Annual Survey of Manufacturers. Labor share is defined as the 1997 to 2006 average of the U.S. labor expenditure share for each of the 325 sectors. The labor expenditure share equals expenditures for labor divided by the total expenditure for labor and capital. Because we exclude expenditures for inputs, energy, and transportation, the average labor share is rather high at $85 \%$ (69\% when weighted by total import volume). Only taking into account labor and capital expenditures, however, leads to a clear measure of labor versus capital intensity.

\footnotetext{
${ }^{8}$ Due to this averaging, LWC import share could theoretically exceed $100 \%$ towards the end of the sampling period. This is never the case in any of the 325 industries. The Annual Survey of Manufacturing does not report U.S. domestic shipments for all years and all industries. Whenever the value of domestic shipment is missing, we then average over the available values and use the resulting measure over the entire sampling length.
} 


\subsection{LWC Import Competition Over Time}

As shown in Figure 1, in 2006, the nine examined LWCs accounted for imports worth more than $5.5 \%$ of U.S. GDP, equivalent to roughly 600 billion dollars or one-third of total U.S. imports. Even more impressive is the growth rate of trade with this group of countries: in 1997, they accounted for imports worth a mere $2.5 \%$ of U.S. GDP.

In which sectors is import competition from China and the other countries of this study most intense? Has the composition of these imports changed over time? Figure 2 documents that low-wage import competition is concentrated in labor intensive sectors. The upper scatter plot of Figure 2 relates the volume of U.S. imports from the nine LWCs normalized by U.S. sales in 1997 to the sector's labor intensity. Labor intensity is defined as the ratio of the 1997 to 2006 average of labor expenditures over labor plus capital expenditures. Due to the averaging, a sector's labor intensity is constant through time. In 1997, imports were concentrated in laborintensive industries. The lower scatter plot of Figure 2 documents that this relationship is even more pronounced in 2006. In terms of changes, the two scatter plots of Figure 2 also imply that the increase in import competition was concentrated in labor-intensive sectors.

How did the composition of imports from low-wage countries evolve over time? In Figure 3, we describe the evolution of the average labor intensity of U.S. imports originating from China, Mexico, the other seven low-wage countries (Brazil, India Indonesia, Malaysia, the Philippines, Thailand, and Vietnam), and from the rest of the world. ${ }^{9}$

China's imports are by far the most labor intensive. The labor intensity of China's imports has remained remarkably stable through 1997 to 2006. In this period, the labor intensity decreased only slightly from 82.9 to 81.5 percent. In contrast, the labor intensity of imports from Mexico and the group of seven other low-wage economies increased over the last decade. For the case of Mexico, this increase was quite pronounced, with average labor intensity going from $66.8 \%$ in 1997 to $70.9 \%$ in 2006. Most likely, this patter can be explained by Mexico's participation in NAFTA.

\footnotetext{
${ }^{9}$ The measure of average labor intensity of imports is constructed in the following way. A sector's labor intensity $\overline{l s}_{j}$ is the sector's U.S. labor intensity averaged over the 10 years of the sample. For every year, we then calculate $\left(\sum_{j \in J}\right.$ Value $\left.^{\operatorname{Imports}_{j, t}} * \overline{l s}_{j}\right) /\left(\sum_{j \in J}\right.$ Value $\left.\operatorname{Imports}_{j, t}\right)$.
} 
In stark contrast to the conventional wisdom that China and other emerging economies have diversified and switched towards production of more sophisticated goods (see Schott (2004)), we find that the composition of China's exports has remained remarkably stable, while the capital content of imports from the other LWCs has even decreased from 1997 to 2006. In Figure 4, we provide an explanation for this finding. Figure 4 depicts the growth of the capital stock and the growth rate of effective workers in China from 1996 to 2004. The number of effective workers equals the number of workers adjusted for the growth of labor productivity. Effective labor and capital grew at a nearly identical pace, implying that China manly became a larger economy, but did not becoming more capital intensive. Consequently, also the composition of its exports has remained relatively stable.

Together, Figures 1 and 3 imply the following. During 1997 to 2006, the total volume of lowwage imports has nearly tripled in volume and has more than doubled as a share of U.S. GDP. The composition of U.S. imports from these imports has remained nearly unchanged (maybe with the exception of Mexico, which has even specialized into more labor intensive goods). Consequently, the increase in import competition in the decade leading up to 2006 was concentrated in sectors where the nine LWCs already had a comparative advantage in 1997.

\subsection{Factor Intensity, LWC Growth, and Import Competition}

We next document that the interaction of a sector's labor intensity and the growth rate of industrial output in LWCs can explain changes in U.S. low-wage import competition.

In all estimations of Table 1, the dependent variable is the absolute year-to-year change of import competition from a selected country. For example, in Column (1), the dependent variable is the absolute change of imports from China divided by the size of the respective sector in the United States. The U.S. sector size is defined as the value of domestic shipments plus the values of imports from all countries.

In the random effects model of Column (1), the independent variables are the growth of industrial output in China, the sectoral labor expenditure share, and the interaction of the two $\left(g_{\text {china }} \overline{l s}_{j}\right)$. The coefficient of $g_{l w c} \overline{l s}_{j}$ is estimated at +0.665 and is highly significant; that is, when China's industrial capacity grows, exports to the United States increases in labor-intensive 
sectors. In contrast, the main effect of industrial growth is estimated to be negative at -0.445 .

The main and interaction coefficients imply that if the growth rate of Chinese industrial output is $1 \%$, the value of U.S. imports in an industry $k$ with a labor expenditure share of $\overline{l s}_{k}=0.5$ decreases by $\left(\frac{1}{2} 0.665-0.445\right) * 0.01$ or 0.11 percentage points. For the same $1 \%$ change in Chinese output, U.S. imports in an industry $j$ using only labor $\left(\overline{l s}_{j}=1\right)$ increase by $(0.665-0.445) * 0.01$ or 0.22 percentage points. The unweighted average labor intensity in the sample is 0.85 , so that the average sector will capture an import share of 0.12 percentage points when China's aggregate manufacturing output grows by $1 \%$.

In Column (2), we next add fixed effects to the estimation in order to filter out sectoral trends. Because the labor share is averaged over time and does not vary within a sector, it is dropped from the estimation. Next, in Column (3), we also add time dummies to the estimation. Because the growth of industrial production in China is an aggregate variable, this regressor is dropped from the estimation when time dummies are introduced.

Columns (4) to (6) repeat the specification of Column (3) for imports from Mexico, India, and Vietnam. In these specifications and in the rest of the paper, we include time dummies and fixed effects so that the labor share and the aggregate growth rate of these countries are dropped from the estimations. The coefficients for growth interacted with labor intensity are positive and significant. The coefficients are smaller reflecting the fact that these economies are smaller than the Chinese economy.

We next turn to two falsification exercises that are particularly important in the context of the identification restriction made in the next section. The fact that imports grew particularly in labor-intensive sectors may also be the result of U.S. demand shocks that are biased towards labor-intensive goods. As a first falsification exercise, we next repeat the analysis for Canada and Japan in Columns (7) and (8). We find that labor share multiplied by manufacturing growth in the two countries is not significantly correlated with changes in import share.

As a further counterfactual, we instrument for Japanese trade with Japanese growth interacted with skill intensity. The measure of skill intensity is constructed by averaging the U.S. share of non-production workers of total employees averaged over 1997 to 2006. While this measure can predict changes of imports from Japan (see Column (9)), it fails to predict imports from China 
(see Column (10)).

Table 1 documents that there is a systematic relationship between the changes in U.S. imports, growth, and comparative advantage. When labor-abundant LWCs grow, their exports increase much more in labor-intensive sectors than in capital-intensive sectors. When a skill abundant nation such as Japan grows, its exports increase in skill-intensive sectors, yet not in labor-intensive ones.

\section{Identifying the Causal Effect of LWC Imports}

\subsection{Identification Analysis}

It is evident that trade is endogenous to global demand and supply conditions. In this section, we lay out our strategy to instrument for trade flows with those induced by the growth of aggregate productive capacity in LWCs interacted with labor intensity. The exhibition in this section is conducted for prices, but the analysis applies equally to productivity.

We begin with the true relationship between trade and prices. Denote U.S. prices at time $t$ for sector $j$ by $p_{u s, j, t}$, and sectoral U.S. imports from LWCs normalized by the U.S. sector size by $m_{l w c, j, t}$. Denote the industry-specific trend of U.S. prices in sector $j$ by $\alpha_{p, j}$, the common shock to U.S. prices at time $t$ by $\epsilon_{p, t}$, and sector-specific price shocks by $\epsilon_{p, j, t}$. In the United States, the true relationship between price changes and the changes of import competition is given by

$$
\begin{aligned}
\Delta p_{u s, j, t} & =\alpha_{p, j}+\beta \Delta m_{l w c, j, t}+d_{u s, j, t}+\epsilon_{p, t}+\epsilon_{p, j, t}, \\
\Delta m_{l w c, j, t} & =\alpha_{m, j}+\delta \Delta p_{u s, j, t}+\theta \Delta s_{l w c, j, t}+\epsilon_{m, t}+\epsilon_{m, j, t} .
\end{aligned}
$$

In Equation (1), the coefficient of interest is $\beta$, measuring the true impact of an increase in imports from LWCs on sectoral prices. A prior shared by most researchers is that LWC imports lower U.S. prices, i.e., $\beta<0$. Imports, however, also respond to U.S. demand conditions. Apart from the unobserved export supply shocks in LWCs (denoted by $\Delta s_{l w c, j, t}$ ), U.S. prices also influence how much foreign firms export. Finally, $\alpha_{m, j}$ is an industry-specific trend of LWC imports, $\epsilon_{m, t}$ is a common shock to exports to the United States, and $\epsilon_{m, j, t}$ is a sector-specific shock. 
When prices in the United States rise, imports from LWCs most likely increase. Therefore, an OLS estimation of $\beta$ in Equation (1) is biased and the true effect of LWC imports is either underestimated or estimated with the wrong sign. We thus instead focus on a driver of export supply shocks in LWCs, $\Delta s_{l w c, j, t}$.

We denote the growth of industrial output in LWCs by $g_{l w c}$ and a sector's time-invariant labor intensity by $\overline{l s}_{j}$.

Definition 2 (Comparative Advantage-Induced Imports). Denote the element of the change of import volume that can be explained by the sectoral trend $\alpha_{s, j}$, the aggregate growth rate $g_{l w c, t}$, and the interaction of output growth and labor intensity $g_{l w c, t} \bar{l}_{j}$ by $\Delta s_{l w c, j, t}$. By definition,

$$
\Delta s_{l w c, j, t}=\alpha_{s, j}+\widehat{\lambda_{1}} g_{l w c, t}+\widehat{\lambda_{2}} g_{l w c, t} \overline{l s}_{j}+\epsilon_{s, t}+\epsilon_{s, j, t}
$$

The main element of interest in (3) is $g_{l w c, t} \bar{l}_{j}$, the weighted growth rate of LWC industrial output interacted with sectoral labor intensity. This variable is constructed in the following way. We first generate one weight for each LWC country $i$ by averaging (imports from country $i$ /(U.S. domestic shipments + total imports)) over the 325 sectors and over the 10 years. We then construct the weighted growth rate of manufacturing output in the nine LWCs by summing over the growth rates multiplied by the country weight. Finally, we multiply the weighted growth rate by the 1997 to 2006 average U.S. labor expenditure share of sector $j$. Since the labor share varies over industries and the growth rate over time, the instrument varies across both time and sectors.

Since aggregate growth in LWCs may be correlated with aggregate demand in the United States, we do not directly use $\Delta s_{l w c, j, t}$ to instrument for trade. Rather, we evaluate the difference of imports between two sectors $j$ and $k$ that differ in their time labor intensities $\overline{l s}_{j}$ and $\overline{l s}_{k}$, yielding

$$
\begin{aligned}
\Delta p_{u s, j, t}-\Delta p_{u s, k, t} & =\alpha_{p, j, k}^{*}+\beta \frac{\theta \lambda_{2}}{1-\delta \beta}\left(\overline{l s}_{j}-\overline{l s}_{k}\right) g_{l w c, t}+\epsilon_{p, j, k, t}^{*}, \\
\Delta m_{l w c, j, t}-\Delta m_{l w c, k, t} & =\alpha_{m, j, k}^{*}+\frac{\theta \lambda_{2}}{1-\delta \beta}\left(l s_{j}-l s_{k}\right) g_{l w c, t}+\epsilon_{m, j, k, t}^{*} .
\end{aligned}
$$

The reduced-form relationship between labor intensity differentials and price differentials is de- 
rived by substituting Equation (5) into a difference-in-difference version of Equation (2). The reduced-form difference-in-difference specification relating low-wage output growth changes and labor intensity to relative changes in prices is $\epsilon_{p, k, j, t}^{*} \equiv \frac{1}{1-\delta \beta}\left(\left(\epsilon_{p, j, t}-\epsilon_{p, k, t}\right)+\beta \epsilon_{m, j, k, t}^{*}\right)$. By construction, the residuals of any regression are orthogonal to the dependent variables and thus, it is always true that $\epsilon_{m, j, k, t}^{*}$ is orthogonal to $g_{l w c, t}$. Our methodology can therefore establish the true effect of LWC imports if the following condition holds.

Assumption 1. (Identification Restriction)

$$
\left(\epsilon_{p, j, t}-\epsilon_{p, k, t}\right) \perp\left(l s_{j}-l s_{k}\right) g_{l w c, t} .
$$

It is important to note that the orthogonality assumption (6) does not rely on the absence of capital or skill-biased structural shifts in the U.S. economy, nor would it be invalidated if aggregate transitory shocks in the United States did influence growth in LWCs. Our identification assumption is much milder and relies on transitory sector-specific shocks in the United States being orthogonal to the interaction of growth in low-wage economies and a sector's labor intensity.

Temporary shocks in the large U.S. economy can be strong enough to affect both trade volume and growth in the rest of the world. Given our identification strategy, this would bias our results if such shocks were systematically concentrated in labor intensive sectors when growth in lowwage countries is high, and systematically concentrated in capital intensive sectors when growth in low-wage countries is low.

We have already provided a first falsification exercise in the previous section, where we demonstrated that marginal trade flows from Japan and Canada cannot be explained by labor intensity (but by skill intensity). Hence, it cannot be the case that demand in the United States was systematically biased towards labor-intensive goods, which was also causing growth of industrial output abroad. We next examine the orthogonality assumption (6) directly and also contrast our empirical approach to OLS estimates. 


\subsection{Examining the Identification Restriction}

There are three potential concerns with the validity of our identification assumption. First, positive U.S. demand shocks concentrated in labor intensive sectors could cause an increase of labor-intensive imports originating from low-wage countries and, thereby, also cause growth of industrial output in these countries. Second, the same could happen following a shift of U.S. production into capital-intensive sectors. Third, also a shift of the export supply of other countries away from labor-intensive sectors could induce both additional LWC imports in labor intensive sectors and LWC growth. While such shocks are unobserved, they are correlated with changes in U.S. consumption, U.S. production, and U.S. imports from non-LWCs, which are all observable.

We first examine the OLS relation between LWC imports and U.S. non-LWC consumption, defined as the sum of domestically produced goods plus imports from countries other than the nine low-wage countries. If LWC imports increase following a supply shock in LWCs, LWC imports should crowd out U.S. production and imports from the rest of the world, i.e., one should find a negative correlation between LWC imports and U.S. non-LWC consumption. In contrast, if LWC imports increase following a U.S. demand shock, one should observe a positive correlation between these two variables.

We start by documenting the bias of OLS estimates. In Columns 1 and 2 of Table 2 (Panel A), the independent variable is the year-to-year change in LWC imports. The dependent variable is the year-to-year change in the value of domestic shipments plus imports from non-LWC countries. ${ }^{10}$ The change in U.S. consumption has a significant and positive coefficient, i.e., when imports from LWCs increase, non-LWC consumption increases, too. The coefficient is estimated at 0.63 , suggesting that if in sector $j$ LWC imports increase by one percent of the respective U.S. industry size, total U.S. consumption in sector $j$ increases by $1.63 \%$ of the industry size.

The positive correlation between non-LWC consumption and LWC imports could be a result of sector-specific structural trends or temporary aggregate shocks. It may be more reasonable to assume that sector-specific and temporary shocks to LWC imports are uncorrelated with U.S. demand shocks. We document that this is not the case in Column 2, which adds fixed effects

\footnotetext{
${ }^{10}$ In all specifications of Table 2 , in order to ensure comparability with the other estimations of our study, the dependent variables are normalized by average U.S. industry size, defined as 1997 to 2006 average of domestic shipments plus world imports.
} 
by sector and year dummies. The coefficient of the change of non-LWC consumption decreases somewhat, but is still positive, significant, and economically large.

Even temporary and sector-specific shocks to LWC imports are positively correlated with shocks to non-LWC consumption in the United States. This result suggests that the main force driving LWC imports are shocks to U.S. demand rather than to LWC supply.

In contrast, in the instrumental variable estimation in Column 3, we document that the component of LWC imports induced by comparative advantage and LWC-growth is not positively correlated with U.S. consumption shocks. In the second-stage estimation in Panel A, we repeat the specification of Column 2, but instrument for changes of LWC import volume with the comparative advantage-induced component of trade. In the first-stage estimation in Panel B, the independent variable is the interaction of labor intensity and LWC growth. Since the estimation includes year dummies and sector fixed effects, the two interacted variables are not included on their own.

Whereas the OLS correlation between LWC imports and non-LWC consumption is positive, it is negative (but insignificant) once we instrument for imports. The coefficient is estimated at -1.02, implying that when comparative advantage-induced LWC import competition increases, consumption of non-LWC origin decreases to exactly offset the increase in LWC import competition. The fact that instrumented changes in LWC imports fully crowd out consumption from other countries can only be explained by LWC supply shocks, rather than U.S. demand shocks, causing comparative advantage-induced imports.

In the remainder of Table 2, we decompose this crowding out into the effect on U.S. production and on imports from the rest of the world. In Columns 4 and 5, the dependent variable is the absolute change in U.S. domestic shipments. In both specifications, the independent variable is the change in import competition. While changes in import competition are positively correlated with changes of U.S. shipments in the OLS regression in Column 4, they are negatively correlated in the instrumental variable estimation in Column 5 . The (insignificant) point estimate of Column 5 suggests that when LWCs capture one percent market share in sector $j$, this is offset by a reduction of domestic sales by 0.55 percentage points in the same sector.

A last potential concern we address is the presence of shocks to either U.S. import demand (but not demand in general) or of shocks to export supply in the rest of the world. The latter 
shocks could shift U.S. non-LWC imports towards capital intensive goods, thereby causing both additional LWC imports in labor intensive sectors and aggregate LWC growth. In Columns 6 and 7 , the dependent variable is the absolute change in imports from countries other than the nine LWCs. While we find that in the OLS estimation, the correlation of LWC imports and imports from the rest of the world is significant and positive, the relation between these two variables is negative when we instrument for trade flows.

We conclude from these falsification exercises that, while there is strong evidence that LWC imports are endogenous to U.S. demand shocks, the comparative advantage and growth-induced component of imports is not endogenous to U.S. shocks once one adjusts for sectoral trends and temporary aggregate shocks. ${ }^{11}$

\section{Results}

We next turn to our results and present OLS and two-stage least squares (IV) estimates for the difference-in-difference form of Equation (4) relating price changes to changes in import shares. We first explain our strategy and document the large difference between OLS and IV estimates in Table 3. We next present the robustness analysis in Table 4.

As has been argued by Iranzo and Ma (2006), Hanson and Robertson (2008), and others, China may crowd out imports from other low-wage countries such as Mexico. In order to analyze the overall effect of LWC exposure on the United States, rather than the effect of China's imports on U.S. prices compounded with a potential crowding-out channel, we analyze the block impact of the nine countries together.

OLS and IV Estimates: U.S. Producer Prices

In all regressions of Table 3, the dependent variable in Panel $\mathrm{A}$ is the percentage change of the U.S. producer price index for each 6-digit sector. All estimations of Table 3 include fixed effects by sector. We begin our discussion by first presenting OLS estimates of U.S. producer

\footnotetext{
${ }^{11}$ Technically, only shocks that are temporary, sector-specific, specific to goods originating from LWCs, and large enough to spur aggregate growth in LWCs are consistent with the presented counterfactuals. We believe that it is reasonable to assume that such shocks are absent or negligible in the data. It is noteworthy that if these shocks matter in reality, our findings are biased towards underestimating the effect of low-wage import competition on U.S. prices, i.e., even if such shocks are present, we present a valid lower bound for the effect of import competition on U.S. prices.
} 
prices regressed on LWC import share. This empirical strategy relates our findings to the existing literature and highlights the bias in OLS estimations.

Column (1) shows the OLS regression of the annual change in LWC import share on the change of the logarithm of the U.S. producer price. The coefficient is estimated significant and positive, suggesting that imports from low-wage countries tend to increase U.S. prices. Aggregate U.S. and LWC shocks may be more endogenous than shocks at the sectoral level. We therefore introduce the growth of low-income manufacturing output in Column (2). The coefficient remains positive, but is no longer significant. Since variables other than low-income manufacturing may affect U.S. prices, we next introduce year dummies in Column (3).

Column (3) documents that even conditional on all aggregate information (filtered by the year dummies) and abstracting from sectoral trends (filtered by the sector dummies), OLS estimations predict that LWCs have no effect on U.S. prices. While the coefficient is estimated negative, it is far from significant and economically very small: the estimation in Column (3) predicts that even if China and other LWCs were to capture $100 \%$ of a U.S. market, prices would decrease by only $0.9 \%$.

In contrast, the estimated effect of LWC imports is economically very sizeable and statistically significant when we instrument for the trade flows with the comparative advantage-induced component of trade. In Column (4), we do not introduce year dummies, but we again introduce the weighted LWC growth rate of manufacturing output. Consider the first-stage estimation in Panel B, Column (4). The main coefficient of the growth of manufacturing output in LWCs is estimated at -0.675 , while the interaction coefficient of manufacturing growth rate times labor share is estimated at 1.07. If LWCs grow by one percentage point, the import share increases by $0.395 \%$ in a sector using only labor, while the import share of a sector with labor expenditure share of 0.5 decreases by $0.171 \%$.

Consider next the second-stage estimation in Panel A, Column (4). If LWCs grow, the import share increases in labor-intensive sectors. This comparative advantage-induced component of trade leads to a large downward pressure on prices: the coefficient is estimated at $-3.112 \%$, that is, a $1 \%$ increase in import market share reduces U.S. producer prices by more than three percentage points. 
We next estimate the main specification including fixed effects and year dummies in Column (5). Because the manufacturing output growth rate is one aggregate number per year, it is dropped from the estimation with year dummies. In the specification of Column (5), all sector specific averages and aggregate shocks are filtered out. Again, we find that when imports from LWCs increase by $1 \%$ of the U.S. sector size, prices decrease by around $3 \%$.

Before turning to an explanation of why prices react so dramatically to foreign competition, we first present some robustness tests in Table 4 .

\section{Robustness Analysis}

The structure of Table 4 is the following. Panel A presents the OLS regressions. Panel B presents the second-stage estimation relating instrumented trade flows to changes in prices. Panel C presents the first-stage estimation with changes of the LWC import share as the dependent variable.

We start by adding the lagged level of LWC imports to the estimation. The lag specification controls for the fact that the level of LWC imports might affect prices, since existing imports could become cheaper over time. The regression in Column 1 of Panel B shows that the (lag) level of imports is not significant. Nevertheless, a high level of existing exports can further explain increases in imports (Panel C, Column 1).

Prices might react to changes in imports with a lag, and prices might themselves mean revert. We therefore include the lagged change in the import share in Column (2) and the lagged price change in Column (3). Indeed, each of these two controls reduces the estimated coefficient for the changes of imports somewhat, but the coefficient is still estimated above two and highly significant. In Column (4), we control for productivity growth.

Our sample is characterized by a small number of observations with very large price movements that might not be representative, since they are in raw material-intensive industries such as oil refineries, copper wire, and petrochemical manufacturing where LWC imports do not have an important impact on prices. We have thus excluded 35 NAICS-Year observations based on the criterion that the absolute change in the logarithm of the price exceeded 0.25 . The excluded observations are listed in Appendix B. In Column (5), we include the 35 outliers to the estimation. The estimated coefficient nearly doubles and is again highly significant. 
The Hecksher-Ohlin theory of trade and its modern extensions not only make predictions about trade flows, but also about net trade flows (imports minus exports). We therefore instrument for the change in net imports in Column (6). We find that also net trade flows are well explained by our instrumentation strategy and that comparative advantage-induced net imports have a profound effect on U.S. producer prices.

In Column (7), we analyze the special role of China. In Panel C, we instrument for the change of Chinese imports with the growth of manufacturing production in China interacted with U.S. labor intensity. The highly significant coefficient in Panel B suggests that Chinese exports have a slightly stronger effect on U.S. prices than imports from other LWCs (compare Column 5 of Table 3 and Column 7 of Table 4).

Table 4 documents that our instrumentation strategy can predict changes in LWC imports for a wide variety of specifications. The same table also documents that the estimated effect of LWC trade on prices is statistically significant and economically large. In Panel A, we also show that the OLS bias is sizeable for all specifications. We next analyze the precise channels through which trade has affected prices.

\section{Decomposing the Impact of Import Competition}

The per unit cost of a good can be expressed as the product of the cost of all inputs used in the production of the good divided by the productivity with which these inputs are used. A good's price can be expressed as the per unit cost of the good multiplied by (one plus the markup). Hence, abstracting from aggregation issues, the percentage change of the sectoral average price can be decomposed into the contribution of cost of input changes $\left(\Delta c_{j, t}\right)$, changes in productivity $\left(\Delta a_{j, t}\right)$, and changes in one plus the markup $\left(\Delta\left(1+\pi_{j, t}\right)\right)$ (always in $\left.\%\right)$ :

$$
\Delta p_{j, t}=\Delta c_{j, t}-\Delta a_{j, t}+\Delta\left(1+\pi_{j, t}\right)
$$

With this de-composition in mind, in this section, we set out to analyze why prices react so strongly to import competition.

U.S. Labor Productivity 
To measure U.S. productivity growth, we use output per hour worked from the Annual Survey of Manufacturers as the dependent variable. Table 5 repeats the basic specification of Column (5) in Table 3 and the robustness tests of Table 4, but with productivity as the dependent variable. Because the first stage is identical to that of Table 3, it is not reported. Panel A presents the OLS results, while Panel B of Table 5 presents the two-stage least squares estimates.

In Column (1), we present the baseline estimation including only fixed effects and year dummies, and the interaction of LWC growth and labor intensity. A one percentage point increase in imports is associated with a $2.375 \%$ increase in sectoral productivity. Hence, of the $3.1 \%$ total percent price change, over three-fourths are explained by productivity growth.

In the robustness tests presented in Table 5, the magnitude of productivity changes is comparable to the baseline result of Column 1. It is economically large, but significant only in five of the eight specifications. The robustness tests are identical to those of Table 4, except in Column 5. Here, we add the lagged change of productivity rather than the contemporaneous change as a control.

The IV regressions in Panel $\mathrm{B}$ again underscore the bias of OLS regressions in Panel A. Although the coefficients for the effect of imports on productivity in Panel A have the right sign in seven out of eight cases, the magnitude of the coefficients in the OLS regression is around $0.4 \%$, or only one-sixth of the true effect.

Wages and Input Costs

While productivity explains a large part of the price-dampening effect of import competition, costs might also be affected by trade. In Table 6 , we examine the effect of imports on wages and on the cost of input goods. We present the OLS estimations in Panel A, the instrumental variable estimations in Panel B, and the first-stage estimations in Panel C.

In Columns (1) to (3), the dependent variable is the change in the logarithm of the hourly wage of production workers in each sector. Column (1) presents the baseline estimation, Column (2) controls for U.S. productivity growth, and Column (3) controls for lagged changes of worker wages. While the OLS regressions in Panel A suggest that competition from LWCs tends to decrease the hourly wages of production workers, this is not supported by the IV estimations.

Rather, the coefficient of changes of the import share is estimated to be positive, although 
not statistically significant. A potential explanation for the positive correlation is that productivity increases considerably when import competition increases, therefore benefiting production workers. This result, however, does not imply that low-skilled workers do not suffer from import competition: the absence of any industry-specific effect could also be the consequence of workers being mobile across industries. As a result, differences between sectors are non-responsive to import competition.

While sector-specific wages seem not to be affected, low-cost imports might nevertheless affect the cost of production since they reduce the costs of inputs. In Column (4), we analyze the effect of imports on the change in the cost of materials purchased. The dependent variable is the change in the logarithm of the cost of material divided by the value of shipments. Interestingly, although far from significant, the ratio of the costs of inputs does drop considerably (see Panel B) when imports from low-cost producers increase.

To further investigate the importance of input goods, we directly analyze whether the response of prices to imports is different in sectors that contain more or less intermediate goods, inputs, and parts. We construct a measure of input intensity following Schott (2004) and split the sample into sectors that do or do not contain inputs.

Column (5) only includes 6-digit NAICS sectors that do not include 10-digit HS goods code containing the words "Parts", "Input", or related abbreviations in the sector description. The first stage is well identified and the effect of imports on prices is estimated at -2.339 , comparable to our baseline estimate.

In the estimations of Columns (6) to (8), the sample is restricted to the 6-digit NAICS sectors that include at least one 10-digit HS sector with "Parts", "Input", or related abbreviations in the sector description and a non-zero trade flow. In the OLS regressions of Panel A, the response of prices in the sector with inputs and without (Column (5) and (6)) have similar coefficients, and the impact of imports is comparable to or greater for sectors that do not have imports.

However, when we turn to the instrumental variable estimations, a different issue arises. Our instrumentation strategy cannot explain trade flows in the sample containing input goods. Also, when we add additional instruments, the first and second lag of manufacturing growth in LWCs interacted with labor intensity, in Column (7), or instrument for the change of net imports in 
Column (8), the first-stage estimation is not significant. Consequently, the second-stage estimation is weakly identified.

In sum, our instrumentation strategy does not predict the intermediate good content of trade and therefore does not capture the "cost channel" effect of inputs from China and similar countries, but rather the pro-competitive effect of low-wage country imports.

\section{$\underline{\text { U.S. Markups }}$}

The first four columns of Table 7 present the relationship between changes in U.S. imports from nine LWCs and changes in markups and profits of domestic U.S. firms. Panel A displays the OLS results and Panel B the two-stage least squares estimations. Markups are defined as one minus the ratio of variable costs divided by the value of shipments. Column (1) displays the basic regression for markups, Column (2) adds productivity growth in the U.S. as a control and Column (3) adds the lagged change in markups as a control. Column (4) presents the baseline regression for profits defined as one minus total costs over the value of shipments.

The OLS regressions in Panel A suggest that import competition is associated with increasing markups and profits. The sign of the instrumental variable coefficients are of the opposite sign, although they are again not significant. However, it is noteworthy that the sign of the coefficients are within the right order of magnitude. Consider the baseline estimation including only year dummies and fixed effects. In the baseline estimation of Column 5 in Table 3, a $1 \%$ increase in import competition is associated with a 3.1 percentage point drop in prices. This drop is nearly fully explained by a $2.4 \%$ increase in productivity and a $0.35 \%$ decrease in markups (see Column (1) of Tables 4 and 6).

\section{Demand Elasticity and the Effect of LWC Trade}

The results presented so far highlight the importance of the productivity reshuffling channel of Melitz (2003) as the main channel through which LWC imports affect U.S. industry. We next document that the response of trade volume, prices, and productivity to growth in LWCs varies across the dimension of the elasticity of substitution as predicted by the Melitz model.

We document that while the response of import volume to output growth in LWCs is much 
more pronounced in sectors with elastic demand, the response of prices and productivity to a given increase in import volume is much larger in sectors with inelastic demand. While these differential responses are present in the short run, they are even more pronounced in the long run.

In Columns (5) to (8) of Table 7 , we split the sample by the median elasticity of substitution. The elasticities we use are estimated by Broda and Weinstein (2006), following the methodology of Feenstra (1994). There are two striking findings. First, the response of import volume to growth in LWCs is much stronger in sectors with elastic demand (see Panel C). This finding is intuitive given that we estimate the instantaneous response of import volume to growth in LWC output capacity. Foreign firms find it easier to penetrate markets with elastic demand. ${ }^{12}$

Second, for a given change in import volume, the response of prices and productivity is larger in sectors with inelastic demand (see Panel B). Also this result is intuitive: a given level of import competition implies a much larger change in profits when the elasticity of substitution is low. Consequently, a much larger crowding out effect of unproductive firms occurs. ${ }^{13}$

We next analyze the time dimension of how imports, prices, and productivity react to growth in LWCs and we again evaluate whether this reaction is different for sectors with different demand elasticities. We are interested in how imports react in the long run to the growth in LWCs. We are also interested in how prices react in the long run to imports.

In Columns (1) to (5) of Table 8 (see Panel A), we check whether imports react to lagged growth in LWCs. We begin by adding the lagged manufacturing growth times the average labor share of the sector in Column (1), and we successively also add the second and third lags in Columns (2) and (3). Then in the next two columns, we keep the three lags, but we again split the sample by the median elasticity of demand, which equals 5.55 . We find that overall, most of the response of imports to growth in LWC is instantaneous and that also the major difference in

\footnotetext{
${ }^{12}$ Chaney (2008) shows that sectors with inelastic demand offer higher profits and, therefore, the additional set of firms that start exporting is larger when the elasticity is low. This long-run "distorted-gravity" effect is absent in our data.

${ }^{13}$ For example, when firms face demand from consumers with love of variety utility function $u=\left(\sum_{i \epsilon I} x_{i}^{\frac{\epsilon-1}{\epsilon}}\right)^{\frac{\epsilon}{\epsilon-1}}$, firm $i$ 's profits in equilibrium are equal to a share of $1 / \epsilon$ of revenue minus the fixed costs of operating the business. When all domestic firms in the industry lose $1 \%$ of their revenue to foreign competitors, ceteris paribus, the absolute loss in profits is the largest in low-elasticity industries. Since the exit rate of unproductive firms depends on profitability, the response of industry to a $1 \%$ increase in foreign competition is more pronounced if the elasticity of demand is low.
} 
how high- and low-elasticity sectors are affected by growth is instantaneous.

There is also evidence that imports react with a lag and that this is more pronounced in sectors with elastic demand. In Columns (3), (4), and (5), the single coefficients for the lags of LWC growth interacted with labor intensity are not significant. However, the joint test that the sum of the lagged coefficient equals zero cannot be rejected at the $5 \%$ level. In addition, a test that the long-run response of imports differs for sectors with elastic and inelastic demand cannot be rejected at the $5 \%$ level.

In Columns (6) to (10) of Table 8 (see Panel B), we investigate the long-run response of prices to growth in LWCs. There are three ways in which prices might be affected dynamically. Prices might respond in a staggered way to changes in imports. Second, Columns (1) to (5) document that the response of trade flows to growth in LWCs is somewhat staggered, itself. Last, prices might be autoregressive. We therefore present reduced-form estimations that directly relate our (lagged) instrument to price changes and we also control for lagged price changes.

In Column (6), we add the first lag of our instrument and the lagged price change. We add the second and third lags in Columns (7) and (8). The estimations reveal that prices display non-trivial mean reversion. While there is no effect of the first and second lag of LWC growth on U.S. prices, there is a significant effect of the third lag of the growth in LWCs. In Columns (3) to (5), we documented that the price response is not the result of imports reacting with a lag to growth. Consequently, the staggered response of prices to our instrument must be the consequence of prices reacting with a lag to import competition.

We next split the sample by the median elasticity of substitution in Columns (9) and (10) and obtain two interesting findings. First, the instantaneous response of prices to growth in LWCs is about the same in sectors with high and low elasticity of substitution. Second, the response is markedly different after three years.

In the reduced-form estimation, prices react strongly to lagged manufacturing growth in inelastic sectors. This result cannot be explained by the response of imports to lagged growth (see Columns (4) and (5) of Panel A), so it must be the long-term response of prices to a given level of import competition that differs between sectors with different demand structures.

This differential response of prices in the long term can be rationalized in the context of the 
existing literature. A given level of import competition leads to much greater losses of profits in a sector with inelastic demand. Therefore, the long-term exit of unproductive firms and consequent productivity growth is much more pronounced in these sectors. ${ }^{14}$

\section{Conclusion}

In this study, we document that imports from China, Brazil, Indonesia, India, Malaysia, Mexico, the Philippines, Thailand, and Vietnam had a pronounced effect on prices and productivity in the US.

The main novelty of our empirical strategy is to construct an instrument for trade that is directly based on comparative advantage. We first document that imports from low-wage countries are concentrated in labor-intensive sectors and that over the last decade, the composition of imports has remained remarkably stable, while import volume grew strongly. Consequently, the increase in low-wage import competition was concentrated in labor intensive sectors. We next show that the relative increase of import competition in labor intensive sectors was most pronounced in the years when the growth of industrial output in the emerging economies was the highest, i.e., that the interaction of a sector's labor intensity and output growth in low-wage countries can explain changes in import competition in the US.

Second, we demonstrate that the temporary and relative component of imports induced by labor intensity and output growth in the examined nations is orthogonal to U.S. supply and demand shocks and can, therefore, be utilized to identify the causal impact of import competition on prices.

In a panel covering 325 manufacturing industries from 1997 to 2006, we find that low-wage import competition had a strong impact on prices and productivity. A baseline estimate is that when the nine examined nations capture 1\% market share in the U.S., producer prices decrease by $3 \%$, with about three-fourths of this change due to productivity growth and the remainder due to the reduction of markups. We find no evidence that cheap imported intermediate goods lower

\footnotetext{
${ }^{14}$ We have no understanding why the differential effect occurs exactly after three years rather than smoothly through time. We have also evaluated longer horizons, but three years is the lag at which the response diverges across sectors with different elasticities.
} 


\section{U.S prices.}

The empirical findings based on our instrumentation strategy uncover much stronger effects of globalization than is commonly assumed and reverse, for example, the "China does not matter" verdict reached by Kamin et al. (2006). However, our methodology abstracts from factors such as the increase in global raw material prices that growth in emerging economies has caused and we also do not analyze the optimal response of the monetary authority to these relative price shocks.

With these limitations in mind, the aggregate effect of low wage imports on inflationary our results suggest is the following. On average from 1997 to 2006, low-wage import competition has risen by 0.89 percentage points per year in the industries covered in this study and, therefore, the U.S. PPI inflation rate in manufacturing was reduced due to import competition by nearly 2.7 percentage points each year, while productivity growth was increased by around two percentage points.

Although manufacturing prices make up only a fraction of PPI inflation and producer price inflation is passed through imperfectly to consumers, the aggregate effect of imports from the newly developing world surely cannot be neglected. 


\section{References}

[1] Bai, C. E., Hsieh, C. T., Qian, Y., 2006. The return to capital in China, NBER Working Paper Series No. 12755.

[2] Ball, L. M., 2006. Has globalization changed inflation?, NBER Working Paper Series No. 12687.

[3] Bernard, A. B., Jensen, J. B., Schott, P. K., 2006. Survival of the best fit: Exposure to low-wage countries and the (uneven) growth of U.S. manufacturing plants, Journal of International Economics 68(1), 219-237.

[4] Bernard, A. B., Redding, S. J., Schott, P. K., 2007. Comparative advantage and heterogeneous firms, Review of Economic Studies 74(1), 31-66.

[5] Borio, C. E.V., Filardo, A., 2007. Globalisation and inflation: New cross-country evidence on the global determinants of domestic inflation, Bank for International Settlements Working Paper 227.

[6] Bosworth, B., Collins, S. M., 2007. Accounting for growth: Comparing China and India, NBER Working Paper Series No. 12943.

[7] Broda, C., Weinstein, D., 2006. Globalization and the gains from variety, Quarterly Journal of Economics 121(2), 541-585.

[8] Chaney, T., 2008. Distorted gravity: The intensive and extensive margins of international trade, American Economic Review, forthcoming.

[9] Chen, N., Imbs, J., Scott, A., 2007. The dynamics of trade and competition, University of Lausanne, mimeo.

[10] Chor, D., 2007. Unpacking sources of comparative advantage: A quantitative approach, MIME, Singapore Management University, mimeo.

[11] Davis, D. R., Weinstein, D. E., 2001. An Account of Global Factor Trade, American Economic Review 91(5), 1423-1453. 
[12] Feenstra, R., 1994. New product varieties and the measurement of international prices, American Economic Review 84(1), 157-177.

[13] Feyzioglu, T., Willard, L., 2008. Does inflation in China affect the United States and Japan?, China and World Economy 16(1), 1-16.

[14] Gamber, E. N., Hung, J. H., 2001. Has the rise in globalization reduced U.S. inflation in the 1990s?, Economic Inquiry 39, 58-73.

[15] Hanson, G. H., 2003. What has happened to wages in Mexico since NAFTA? Implications for hemispheric free trade, NBER Working Paper Series No. 9563.

[16] Hanson, G. H., Robertson, R., 2008. China and the manufacturing exports of other developing countries, University of California, San Diego, mimeo.

[17] Hummels, D., 2001. Toward a geography of trade costs, Krannert School of Management, Purdue University, mimeo.

[18] International Monetary Fund, 2006. How has globalization affected inflation?, Chapter 3 in: World Economic Outlook: Globalization and Inflation, 92-134.

[19] Ihrig, J., Kamin, S. B., Lindner, D., Marquez, J., 2007. Some simple tests of the globalization and inflation hypothesis, Board of Governors of the Federal Reserve System, International Finance Discussion Papers 891.

[20] Iranzo, S., Ma, A. C., 2006. The effect of China on Mexico-U.S. trade: Undoing NAFTA?, University of California, San Diego, mimeo.

[21] Glatzer, E., Gnan, E., Valderrama, M. T., 2006. Globalization, import prices and producers in Austria, Monetary Policy and the Economy, Austrian National Bank No. 3, 24-43.

[22] Kamin, S. B., Marazzi, M., Schindler, J. W., 2006. The impact of Chinese exports on global import prices, Review of International Economics 14(2), 179-201.

[23] Melitz, M., 2003. The impact of trade on intra-industry reallocations and aggregate industry productivity, Econometrica 71, 1695-1725. 
[24] Pain, N., Koske, I., Sollie, M., 2006. Globalisation and inflation in the OECD economies, OECD Economics Department Working Paper No. 524.

[25] Romalis, J., 2004. Factor proportions and the structure of commodity trade, American Economic Review 94(1), 67-97.

[26] Schott, P. K., 2004. Across-product versus within-product specialization in international trade, The Quarterly Journal of Economics 119(2), 647-678.

[27] Tootell, G. M. B., 1998. Globalization and U.S. inflation, Federal Reserve Bank of Boston, New England Economic Review, July/August, 21-33.

[28] Trefler, D., 1993. International factor price differences: Leontief was right, Journal of Political Economy 101(4), 961-987.

[29] Trefler, D., 1995. The case of the missing trade and other mysteries, American Economic Review 85(5), 1029-46.

[30] Wheeler, T., 2008. Has trade with China affected UK inflation?, External MPC Unit Discussion Paper No 22, Bank of England. 


\section{Appendix A: Data Sources}

Industrial production (For China, there is no reliable estimate of Manufacturing Production)

China: IMF International Financial Statistics

Manufacturing production: Mexico: IMF International Financial Statistics; The Philippines: IMF International Financial Statistics; India: Datastream Malaysia: Datastream; Brazil: OECD Main Economic Indicators; Indonesia: OECD Main Economic Indicators; Canada: OECD Main Economic Indicators; Germany: OECD Main Economic Indicators; Japan: OECD Main Economic Indicators; Thailand: Bank of Thailand

Vietnam: General Statistics Office of Vietnam;

Definition of: Markups

$$
\begin{gathered}
\text { Markup }=(\text { Value Added - Total Compensation to Employers }) / \text { Value Shipments } \\
\text { Value Added }=\text { Value of Shipments - Cost of Materials, Fuels, Electricity } \\
\text { Markup }=(\text { Value of Shipments - Variable Costs }) / \text { Value of Shipments } \\
\text { Variable Costs }=\text { Cost of Materials, Supplies, Fuels, Electricity+ } \\
\text { Total Compensation Paid to Employers }
\end{gathered}
$$

Skill intensity $=($ number of employees - average number of production workers $) /$ number of employees

Value Added is compiled by the BLS and also adjusts for changes in inventories, and the income from merchandise operations.

Data Sources for Figures 1 to 4

Figure 1: United States International Trade Commission; Figure 2: Trade data are from the United States International Trade Commission. Labor share is from the U.S. Annual Survey of Manufacturers and is defined as total compensation of employees divided by total compensation of employees and total capital expenditures; Figure 3: labor intensity, see Figure 2; Figure 4: Real capital stock is from B. Bosworth used in Bosworth and Collins (2007). Effective labor supply: total number of persons employed in China (Asian Development Bank) times real manufacturing wage growth in China (nominal wage growth from Laborstat database ILO and GDP deflator from the World Bank Development Indicators). 


\section{Appendix B: List of Outliers}

35 NAICS-Year observations were excluded because the absolute year-to-year price change exceeded $0.25 \log$ points.

Table A - Observations with Absolute Change of Ln Price $>0.25$

\begin{tabular}{|c|c|c|}
\hline Year & Naics & Sector Names \\
\hline 2003 & 311212 & Rice Milling \\
\hline 1999 & & \\
\hline 2002 & 311512 & Creamery Butter Manufacturing \\
\hline $1998,2003,2004$ & 311613 & Rendering and Meat Byproduct Processing \\
\hline 1998 & 312221 & Cigarette Manufacturing. \\
\hline 2003 & 321212 & Softwood Veneer and Plywood Manufacturing \\
\hline 2003 & 321219 & Reconstituted Wood Product Manufacturing \\
\hline $1998,1999,2001,2002,2004,2005$ & 324110 & Petroleum Refineries \\
\hline 2004 & 325110 & Petrochemical Manufacturing \\
\hline 2004 & 325181 & Alkalies and Chlorine Manufacturing \\
\hline 2005 & 325182 & Carbon Black Manufacturing \\
\hline 2004 & 325211 & $\begin{array}{l}\text { Plastics Material and Resin Manufacturing } \\
\text { Nitrogenous Fertilizer Manufacturing }\end{array}$ \\
\hline $2000,2001,2003$ & 325311 & \\
\hline 2005 & 326122 & Plastics Pipe and Pipe Fitting Manufacturing \\
\hline 2000 & 327420 & Gypsum Product Manufacturing \\
\hline 2004 & 331111 & Iron and Steel Mills \\
\hline 2004 & 331112 & Electrometallurgical Ferroalloy Product Manufacturing \\
\hline 2004 & 331222 & Steel Wire Drawing \\
\hline $2003,2004,2005$ & 331411 & Primary Smelting and Refining of Copper. \\
\hline 2006 & 331419 & Primary Smelting and Refining of Nonferrous Metal \\
\hline 2005,2006 & 331421 & Copper Rolling, Drawing, and Extruding \\
\hline 2004 & 332311 & $\begin{array}{l}\text { Prefabricated Metal Building and } \\
\text { Component Manufacturing }\end{array}$ \\
\hline 2000 & 334414 & Electronic Capacitor Manufacturing. \\
\hline
\end{tabular}




\section{Appendix C Sample Criterion}

The sample criterion for the nine LWCs in this study is the following. We define a nation to be "low-wage" if it's non-PPP adjusted GDP per capita in 2005 is less than $20 \%$ of U.S. income per capita. There are 133 LWCs for which we have both trade and GDP (per capita) information (source: World Bank Development Indicators), but most of these countries account for only a very small fraction of U.S. imports. Furthermore, most countries do not publish reliable information about their manufacturing output. We thus drop all countries that account for less than $0.4 \%$ of U.S. imports in 2005. There are 17 remaining economies that have less than $20 \%$ of U.S. GDP per capita and account for more than $0.4 \%$ of U.S. world imports. We next exclude all countries where raw materials account for more than $30 \%$ of U.S. imports. We next exclude all countries where raw materials account for more than $30 \%$ of U.S. imports. ${ }^{15}$ The latter criterion excludes Angola, Algeria, Chile, Colombia, Iraq, Nigeria, the Russian Federation, and Venezuela.

In total, we end up with nine countries that account for $87 \%$ of U.S. non-raw material imports from LWCs. They are China, Brazil, India, Indonesia, Malaysia, Mexico, the Philippines, Thailand, and Vietnam. In 2005, these nine countries accounted for $37 \%$ of non-raw material U.S. imports and for $32 \%$ of all U.S. imports.

How would altering the criterion affect our sample? Changing the cut-off of a "low-wage" country to $10 \%$ of U.S. GDP per capita excludes Brazil, Mexico, and Malaysia. Altering the level at which a country is dropped from our data set because it exports mostly raw materials has no big effect on the composition of our sample. We would include Chile if the cut off is higher than $35 \%$, and the next country to be included is Colombia if the cut off is above $59 \%$. Furthermore, Mexico has the highest raw material import share of the included countries at $16 \%$. Last, if we also include countries with less than $0.4 \%$ of total U.S. imports, this adds a large number of countries, yet only very little trade volume. For example, lowering the cut-off to $0.3 \%$ would add only Turkey, and lowering it to $0.2 \%$ would also add the Dominican Republic, Argentina, Honduras, Costa Rica, and Pakistan. These additional countries, in total, account for only $1.5 \%$ of U.S. imports and $3.8 \%$ of non-raw material imports from LWCs.

\footnotetext{
${ }^{15}$ Raw material imports are defined as the sum of imports in sectors (Harmonized System) 27 (mineral fuels), 7106, 7108, 7110, 74, 7502, 7601, 7801, 7901, and 8001 (different unwrought metals).
} 
Table 1 - Growth of Manufacturing Output, Factor Intensity, and Imports (Panel Estimations)

\begin{tabular}{|c|c|c|c|c|c|c|c|c|c|c|}
\hline & (1) & (2) & (3) & (4) & (5) & (6) & (7) & (8) & (9) & (10) \\
\hline US Imports originating from & China & China & China & Mexico & India & Vietnam & Canada & Japan & Japan & China \\
\hline Panel Estimation with & $\begin{array}{c}R E \text {, w/o ye ar } \\
\text { dummies }\end{array}$ & $\begin{array}{c}F E \text {, wo year } \\
\text { dummies }\end{array}$ & $\begin{array}{c}F E \text {, with year } \\
\text { dummies }\end{array}$ & $\begin{array}{c}F E \text {, with year } \\
\text { dummies }\end{array}$ & $\begin{array}{c}F E \text {, with year } \\
\text { dummies }\end{array}$ & $\begin{array}{c}F E \text {, with year } \\
\text { dummies }\end{array}$ & $\begin{array}{c}F E \text {, with year } \\
\text { dummies }\end{array}$ & $\begin{array}{c}F E \text {, with year } \\
\text { dummies }\end{array}$ & $\begin{array}{c}F E \text {, with year } \\
\text { dummies }\end{array}$ & $\begin{array}{c}F E \text {, with yea } \\
\text { dummies }\end{array}$ \\
\hline
\end{tabular}

Dependent Variable

Dependent variable is the y/y absolute change of (Co untry Imports / (US Ind us try Size+World Imports))

\begin{tabular}{lccc}
\hline Labor Share & -0.051 & & \\
& {$[0.016]^{* *}$} & & \\
& -0.445 & -0.447 & \\
Growth Indus trial Production & {$[0.093]^{* *}$} & {$[0.093]^{* *}$} & \\
in Ch ina & 0.665 & 0.668 & 0.667 \\
Growth Ind. Prod. China * & {$[0.108]^{* *}$} & {$[0.108]^{* *}$} & {$[0.107]^{* *}$} \\
Labor Share & &
\end{tabular}

Growth Manufact. Mexico *

Labor Share

0.121

$[0.044]^{* *}$

Growth Manufact. Mexico*

Labor Share

0.062

$[0.022]^{* *}$

Growth Manufact. V ietnam*

Labor Share

Growth Manufact. Canada *

Labor Share

0.021

$[0.014]^{* *}$

Growth Manufact. Japan*

Labor Share

0.078

[0.052]

Growth Manufact. Japan *

Skill Intensity

0.210

Growth Ind. Prod. China *

Skill Intensity

Fixed Efrects

Observations

Sectors

R-Squared (within)

$325 \quad 325$

$0.082 \quad 0.087$

$0.106 \quad 0.03$

0.023

$0.023 \quad 0.027$

$0.027 \quad 0.024$

$0.024 \quad 0.046$

$[0.036]^{* *}$ (7), in (7), and Japan in Columns (8) and (9). The dependent variable is the year to year in the level of Import from the respective country divided by the U.S. industry size. U.S. Ind ustry Size is defined as except (1) and (2) include year dummies, and all specifications exc ept (1) include fixed effects (FE) by ind ustry; * significant at $5 \%$; ** significant at $1 \%$ 
Table 2 - Examining the Identifying Restriction (Panel Estimations)

\begin{tabular}{|c|c|c|c|c|c|c|c|}
\hline & (1) & (2) & (3) & (4) & (5) & (6) & (7) \\
\hline Estimation: & oLS & oLS & IV & $O L S$ & IV & $O L S$ & IV \\
\hline Dependent Variable & \multicolumn{7}{|c|}{ Panel A: OLS or 2nd Stage - Dep. Var. is the $y / y$ Change of: } \\
\hline $\begin{array}{l}\text { Ch. Imports LWC } \\
\text { (in } \% \text { of U.S. Industry Size) }\end{array}$ & $\begin{array}{c}0.634 \\
{[0.122]^{* *}}\end{array}$ & $\begin{array}{c}0.504 \\
{[0.144]^{* *}}\end{array}$ & $\begin{array}{l}-1.039 \\
{[2.199]}\end{array}$ & $\begin{array}{c}0.147 \\
{[0.130]}\end{array}$ & $\begin{array}{c}-0.552 \\
{[1.924]}\end{array}$ & $\begin{array}{c}0.357 \\
{[0.043]^{* *}}\end{array}$ & $\begin{array}{l}-0.487 \\
{[0.710]}\end{array}$ \\
\hline
\end{tabular}

Within R-Square

0.03

0.14

0.1

0.16

Panel B: First-Stage Estimation - Dep. Var. is the y/y change in (Imports LWC / U.S. industry Size)

\begin{tabular}{|c|c|c|c|c|c|c|c|}
\hline $\begin{array}{l}\text { Labor Share * Ch. \% LWC } \\
\text { Manfct. Output }\end{array}$ & & & $\begin{array}{c}0.601 \\
{[0.227]^{* *}}\end{array}$ & & $\begin{array}{c}0.601 \\
{[0.227]^{* *}}\end{array}$ & & $\begin{array}{c}0.601 \\
{[0.227]^{* *}}\end{array}$ \\
\hline fixed effects & $\mathrm{n}$ & $\mathrm{y}$ & $\mathrm{y}$ & $\mathrm{y}$ & $\mathrm{y}$ & $\mathrm{y}$ & $\mathrm{y}$ \\
\hline Year dummies (both stages) & $\mathrm{n}$ & $\mathrm{y}$ & $\mathrm{y}$ & $\mathrm{y}$ & $\mathrm{y}$ & $\mathrm{y}$ & $\mathrm{y}$ \\
\hline Observations & 1845 & 1845 & 1845 & 1845 & 1845 & 1845 & 1845 \\
\hline Sectors & 325 & 325 & 325 & 325 & 325 & 325 & 325 \\
\hline R-Square (first stage within) & - & - & 0.08 & - & 0.08 & - & 0.08 \\
\hline
\end{tabular}

Notes: Sample is 6-digit NAICS manufacturing industries from 1997 to 2006 (311111-339999). Table 2 presents the relation between LWC on the one and U.S. non-LWC consumption, U.S. domestic shipments, and U.S. non-LWC imports one the other side. non-LWC imports are equal to all U.S imports minus the imports from the nine LWCs. In Columns 1 to 3, the dependent variable is the year-to-year change of (Domestic Production \& non-LWC imports / Avg. U.S. Industry Size). In Columns 4 and 5, the dependent variable is the year-to-year change of (Domestic Production/ Avg. U.S. Industry Size). In Columns 6 and 7, the dependent variable is the year-to-year change of (non-LWC imports / Avg. U.S. Industry Size). Columns 1,2, 4, and 6 present OLS estimation results, while Columns 3,5, and 7 present two-stage least squares results. The first stage is reported in Panel B. Avg. U.S. Industry Size is defined as the 1997-2006 average value of U.S. shipments plus total imports in the respective industry. An industry is measured at the 6-digit NAICS level (only manufacturing industries). All specifications except (1) include year dummies and fixed effects (FE) by industry; * significant at $5 \%$; ** significant at $1 \%$ 
Table 3 - LWC Imports and U.S. Prices: OLS and IV Results (Fixed Effects Panel Estimations)

$\begin{array}{cccccc} & (1) & (2) & (3) & (4) & (5) \\ & \text { w/o year } & \text { Incl. LWC } & \text { with Year } & \text { Incl. LWC } & \text { with Year } \\ & \text { dummies } & \text { Manfct. Growth } & \text { Dummies } & \text { Manfct. Growth } & \text { Dummies } \\ \text { Estimation: } & \boldsymbol{O L S} & \boldsymbol{O L S} & \boldsymbol{O L S} & \boldsymbol{I V} & \boldsymbol{I V}\end{array}$

Panel A: OLS or 2nd Stage - Dep. Var. is the y/y Ln-change U.S. Producer Price

\begin{tabular}{lccccc}
\hline Ch. Imports LWC & 0.232 & 0.048 & -0.009 & -3.112 & -3.097 \\
(in \% of U.S. Industry Size) & {$[0.047]^{* *}$} & {$[0.047]$} & {$[0.047]$} & {$[0.733]^{* *}$} & {$[0.710]^{* *}$} \\
Ch. \% LWC Manfacturing & & 0.508 & & 1.269 & \\
Output & & {$[0.038]^{* *}$} & & {$[0.187]^{* *}$}
\end{tabular}

$\begin{array}{llll}\text { Within R-Square } & 0.01 & 0.08 & 0.11\end{array}$

Panel B: First Stage Estimation - Dep. Var. is the y/y change in (Imports LWC / U.S. industry Size)

\begin{tabular}{lcc}
\hline Labor Share * Ch. \% LWC & 1.070 & 1.073 \\
Manfct. Output & {$[0.200]^{* *}$} & {$[0.197]^{* *}$} \\
Ch. \% LWC Manfacturing & -0.675 & \\
Output & {$[0.172]^{* *}$}
\end{tabular}

Year dummies (both stages)

$\mathrm{n} \quad \mathrm{n}$

n

Observations

2667

2667

$\mathrm{y} \quad \mathrm{n}$

$\mathrm{y}$

Sectors

325

325

2667

2667

2667

R-Square (first stage within)

0.10

Notes: Sample is 6-digit NAICS manufacturing industries from 1997 to 2006 (311111-339999). Panel A of Table 2 displays the relation between changes of imports from nine LWCs and U.S. Producer Prices. The dependent variable is the annual change in the logarithm of U.S. producer price at the 6-digit NAICS level (only manufacturing industries). "Ch. Imports LWC" is defined as the y/y absolute change in (LWC Imports/US Industry Size). U.S. Industry Size is defined as the 1997-2006 average value of U.S. shipments plus world imports. In Columns (2) and (4), "Ch. \% LWC Manfct." is the weighted growth rate of manufacturing output in the nine LWCs. In the lower Panel $\mathrm{B}$ the first-stage relation is displayed and the instrument is the sectoral labor intensity times Ch. \% LWC Manufacturing output. All estimations include fixed effects by sector; * significant at $5 \% ; * *$ significant at $1 \%$ 
Table 4 - LWC Imports and U.S. Prices (Fixed Effects Panel Estimations with Year Dummies)

\begin{tabular}{cccccccc}
\hline & $(1)$ & $(2)$ & $(3)$ & $(4)$ & $(5)$ & $(6)$ & $(7)$ \\
Lagged & Lagged Ch. & Adding Lagged & Adding & Including & Changes in & Chinese \\
LWC imports & LWC Imports & PPI Changes & Productivity & Outliers & NET Imports & Imports
\end{tabular}

Panel A: OLS estimates - Dependent Variable is the y/y Ln-change of the 6-Digit NAICS U.S. Producer Price

\begin{tabular}{lccccc}
\hline $\begin{array}{l}\text { Ch. Imports LWC } \\
\text { (in \% of U.S. Industry Size) }\end{array}$ & 0.006 & 0.036 & 0.034 & -0.030 & 0.131 \\
Ch. NET Imports LWC & {$[0.047]$} & {$[0.051]$} & {$[0.051]$} & {$[0.050]$} & {$[0.064]^{*}$} \\
(in \% of U.S. Industry Size) & & & & -0.092 \\
Ch. Imports China & & & & {$[0.042]^{*}$} \\
(in \% of U.S. Industry Size) & & & & -0.108 \\
\end{tabular}

Panel B: IV Estimates - Dependent Variable is the $y / y$ Ln-change of the 6-Digit NAICS U.S. Producer Price

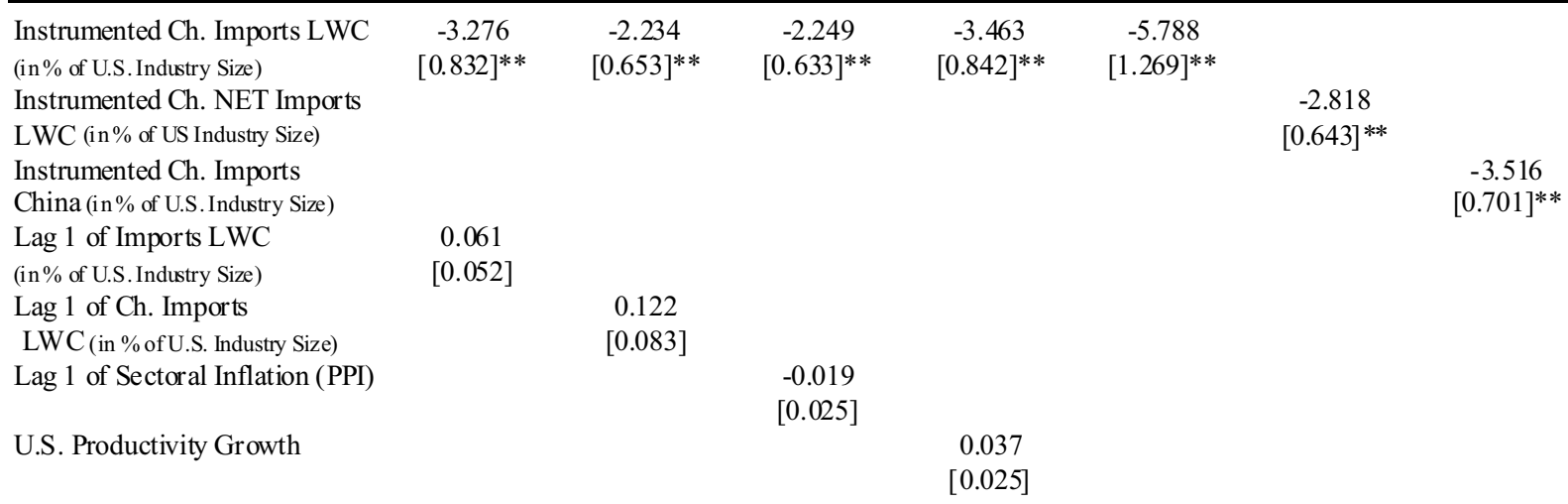

Panel C: First Stage Estimation - Dep. Var. is the y/y Change of

Imports LWC Imports LWC Imports LWC Imports LWC Imports LWC NET Imp. LWC Imports China

Labor Share * Ch. \% LWC

$\begin{array}{llllll}0.962 & 1.059 & 1.104 & 1.03 & 1.007 & 1.18\end{array}$

Manfacturing Output

$[0.216]^{* *} \quad[0.212]^{* *} \quad[0.190]^{* *} \quad[0.222]^{* *}$

Labor Share * Ch. \% Chinese

Manfacturing Output

Lag 1 of Imports LWC

(in \% of US Industry Size)

Lag 1 of Ch. Imports LWC

(in \% of US Industry Size)

Lag 1 of Sectoral Inflation (PPI)

0.035

$[0.010]^{* *}$

$[0.213]^{* *}$

0.755

$[0.116]^{* *}$

U.S. Productivity Growth
0.003
$[0.008]$

0.066
$[0.021]^{* *}$

0.015

$[0.005]^{* *}$

\begin{tabular}{lccccccc}
\hline Observations & 2667 & 2381 & 2345 & 2279 & 2702 & 2667 & 2667 \\
Sectors & 325 & 325 & 325 & 325 & 325 & 325 & 325 \\
R-Square (first stage within) & 0.13 & 0.14 & 0.14 & 0.13 & 0.12 & 0.06
\end{tabular}

Notes: Sample is 6-digit NAICS manufacturing industries from 1997 to 2006 (311111- 339999). All estimations include fixed effects by sector and year dummies Panels A and B of Table 3 presents the relation between changes in U.S. imports from nine LWCs and U.S. producer prices. Panel A displays the OLS results, Panel B the two-stage and B of Table 3 presents the relation between changes in U.S. imports from nine LWCs and U.S. producer prices. Panel A displays the OLS results, Panel B the two-st age level (manufacturing industries). "Ch. Imports LWC" is defined as the y/y absolute change in (LWC Imports/U.S. Industry Size). U.S. Industry Size is defined as the 19972006 average value of U.S. shipments plus world imports. Also "Imports LWC" in(1) is nomalized by the U.S. industry size. "Ch. \% LWC Manufacturing Output" is the weighted average growth rate of manufacturing output in the ni ne LWCs. The instrument employed is the labor intensity times Ch. \% LWC (or Chinese in (7)) manufact uring output. "Productivity" in (4) is the 4-, 5-, 6-digit NAICS productivity growth from the BLS; * significant at 5\%; ** signi fic ant at $1 \%$ 
Table 5 - LWC Imports and U.S. Productivity (Fixed Effects Panel Estimations with Year Dummies)

\begin{tabular}{|c|c|c|c|c|c|c|c|c|}
\hline & $\begin{array}{c}(1) \\
\text { Basic } \\
\text { Specification }\end{array}$ & $\begin{array}{c}(2) \\
\text { Lagged } \\
\text { LWC imports }\end{array}$ & $\begin{array}{c}\text { (3) } \\
\text { Lagged Ch. } \\
\text { LWC Imports }\end{array}$ & $\begin{array}{c}(4) \\
\text { Adding Lagged } \\
\text { PPI Changes }\end{array}$ & $\begin{array}{c}\text { (5) } \\
\text { Adding } \\
\text { Productivity }\end{array}$ & $\begin{array}{c}(6) \\
\text { Including } \\
\text { Outliers }\end{array}$ & $\begin{array}{c}(7) \\
\text { Changes in } \\
\text { NET Imports }\end{array}$ & $\begin{array}{l}\text { (8) } \\
\text { Chinese } \\
\text { Imports }\end{array}$ \\
\hline \multicolumn{9}{|c|}{ Panel A: OLS estimates - Dependent Variable is the $y / y$ US Productivity Growth (BLS) } \\
\hline $\begin{array}{l}\text { Ch. Imports LWC } \\
\text { (in \% of U.S. Industry Size) }\end{array}$ & $\begin{array}{c}0.323 \\
{[0.101]^{* *}}\end{array}$ & $\begin{array}{c}0.329 \\
{[0.101]^{* *}}\end{array}$ & $\begin{array}{c}0.424 \\
{[0.116]^{* *}}\end{array}$ & $\begin{array}{c}0.412 \\
{[0.118]^{* *}}\end{array}$ & $\begin{array}{c}0.331 \\
{[0.101]^{* *}}\end{array}$ & $\begin{array}{c}0.362 \\
{[0.099]^{* *}}\end{array}$ & & \\
\hline $\begin{array}{l}\text { Ch. NET Imports LWC } \\
\text { (in \% of U.S. Industry Size) }\end{array}$ & & & & & & & $\begin{array}{l}-0.012 \\
{[0.089]}\end{array}$ & \\
\hline $\begin{array}{l}\text { Ch. Imports China } \\
\text { (in \% of U.S. Industry Size) }\end{array}$ & & & & & & & & $\begin{array}{c}0.236 \\
{[0.129]}\end{array}$ \\
\hline $\begin{array}{l}\text { Lag } 1 \text { of Imports LWC } \\
\text { (in \% of U.S. Industry Size) }\end{array}$ & & $\begin{array}{c}-0.034 \\
{[0.060]}\end{array}$ & & & & & & \\
\hline $\begin{array}{l}\text { Lag } 1 \text { of Ch. Imports LWC } \\
\text { (in \% of U.S. Industry Size) }\end{array}$ & & & $\begin{array}{c}-0.13 \\
{[0.117]}\end{array}$ & & & & & \\
\hline $\begin{array}{l}\text { Lag } 1 \text { of Sectoral } \\
\text { Inflation (PPI) }\end{array}$ & & & & $\begin{array}{c}-0.109 \\
{[0.041]^{* *}}\end{array}$ & & & & \\
\hline $\begin{array}{l}\text { Lag } 1 \text { U.S. Productivity } \\
\text { Growth }\end{array}$ & & & & & $\begin{array}{c}-0.140 \\
{[0.022]^{* *}}\end{array}$ & & & \\
\hline
\end{tabular}

Panel B: IV Estimates - Dependent Variable is the y/y US Productivity Growth (BLS)

\begin{tabular}{|c|c|c|c|c|c|c|c|c|}
\hline Instrumented Ch. Imports & 2.375 & 2.759 & 2.043 & 1.743 & 2.180 & 2.051 & & \\
\hline LWC (in \% of U.S. Industry Size) & {$[1.022]^{*}$} & {$[1.201]^{*}$} & {$[1.122]$} & {$[1.052]$} & {$[0.960]^{*}$} & {$[1.003]^{*}$} & & \\
\hline Instrumented Ch. NET Impt. & & & & & & & 2.243 & \\
\hline LWC (in \% of US Industry Size) & & & & & & & {$[1.012]^{*}$} & \\
\hline Instrumented Ch. Imports & & & & & & & & 0.407 \\
\hline China (in \% of U.S. Industry Size) & & & & & & & & {$[0.986]$} \\
\hline Lag 1 of Imports LWC & & -0.183 & & & & & & \\
\hline (in \% of U.S. Industry Size) & & {$[0.100]$} & & & & & & \\
\hline Lag 1 of Ch. Imports LWC & & & -0.243 & & & & & \\
\hline (in \% of U.S. Industry Size) & & & {$[0.147]$} & & & & & \\
\hline $\begin{array}{l}\text { Lag } 1 \text { of Sectoral } \\
\text { Inflation (PPI) }\end{array}$ & & & & $\begin{array}{c}-0.107 \\
{[0.043]^{*}}\end{array}$ & & & & \\
\hline Lag 1 U.S. Productivity & & & & & -0.140 & & & \\
\hline Growth & & & & & {$[0.024]^{* *}$} & & & \\
\hline Observations & 2317 & 2317 & 2031 & 1957 & 2279 & 2350 & 2317 & 2317 \\
\hline Sectors & 325 & 325 & 325 & 325 & 325 & 325 & 325 & 325 \\
\hline \multicolumn{9}{|c|}{$\begin{array}{l}\text { Notes: Sample is 6-digit NAICS manufacturing indus tries from } 1997 \text { to } 2006 \text { ( } 311111-339999) \text {. Table } 4 \text { presents the relation between changesin U.S. imports from nin } \\
\text { LWCs and the 4, 5, or 6-digit NAICS annual productivity growth from the BLS. Panel A displays the OLS estimation results and Panel B the two-stage least squares } \\
\text { results. "Ch. Imports LWC" is defined as the y/y absolute change in (LWC Imports/U.S. Industry Size). U.S. Industry Size is defined as the } 1997-2006 \text { average value of } \\
\text { U.S. shipments plus world imports. Also "Imports LWC," "Imports China," and "Net imports LWC" are normalized by U.S. industry size. "Ch. \% LWC Manufacturing } \\
\text { Output" is the weighted average growth rate of manufacturing output in the nine LWCs. The instrument employed is the labor intensity times Ch. \% LWC (or Chinese in } \\
\text { (8)) manufacturing output. All estimations include fixed effects by sector and year dummies. For First Stage see Panel B of Table } 3 \text { (except Column (5)); * significant at } \\
5 \% \text {; ** significant at 1\% }\end{array}$} \\
\hline
\end{tabular}


Table 6 - LWC Imports, Wages, and Input Costs (Fixed Effects Panel Estimations with Year Dummies)

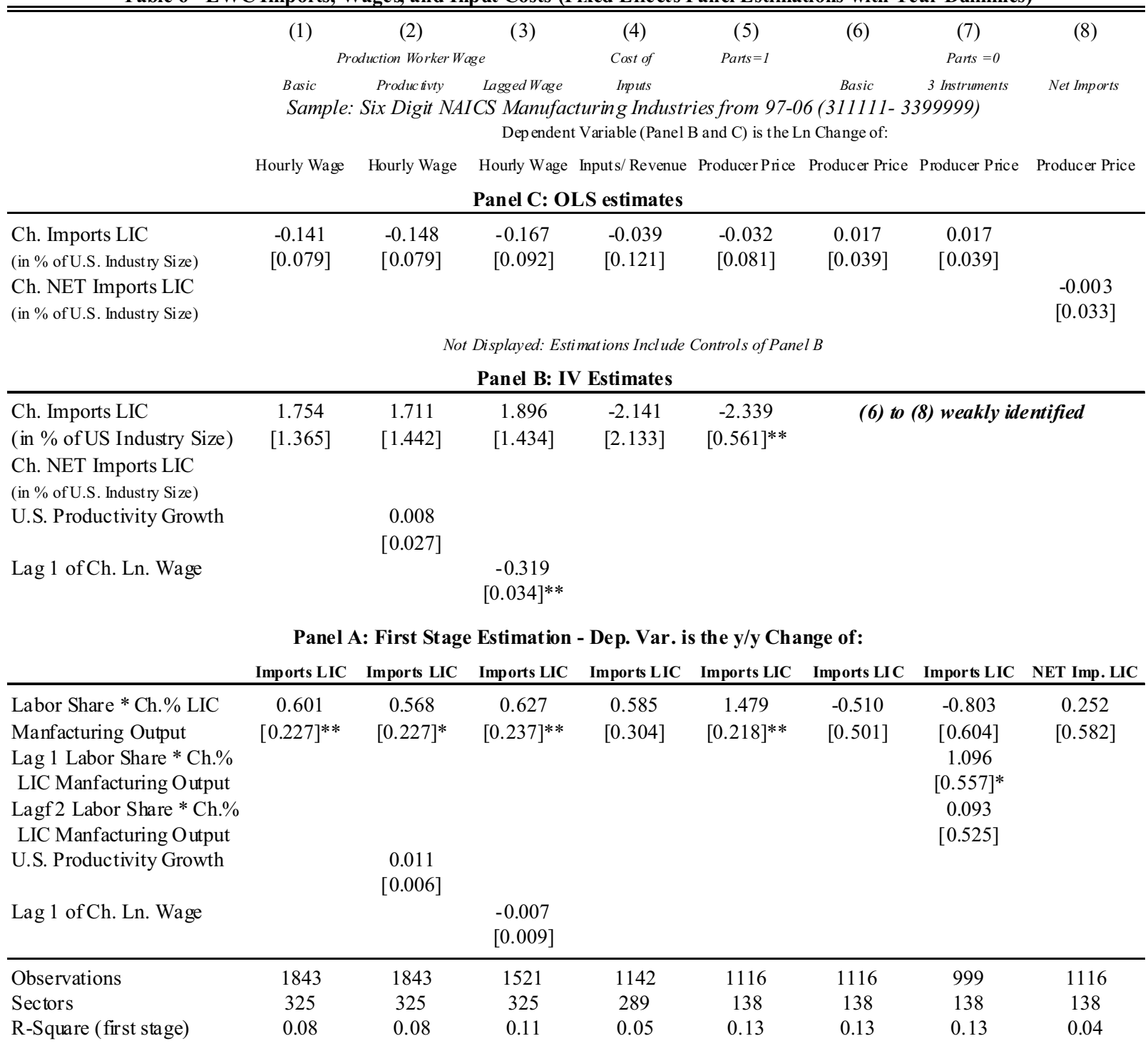

Notes: Sample is 6-digit NAICS manufacturing industries from 1997 to 2006 (311111-339999) . Panels A and B of Table 6 presents the relation between changes in U.S. imports from nine LCs and ch anges in production work er wages, cost of inpu ts, or producer prices. Pan el A displays the OLS results, Pan el B the two-stage least-squares estimations, and Panle $\mathrm{C}$ the first-stage estimations. Worker wage is defined as total wage paymen ts to production workers divided by the total amount of hours worked. Input Costs is defined as the ratio of the cost of inputs over turnover (domestic shipments). Columns (5) to (8) examine the role of intermediate inputs. Column (5) only includes sectors which do not include any 10-digit HS goods code containing the words "Parts, " "Inp ut," or related acronyms and a non-zero trade flow. Columns (6) to (8) contain only the se sectors. The second-stage estimation in (6) to (8) is not displayed since the estimation is weakly identified. "Ch. Imports LWC" is defined as the y/y absolute change in(LWC Imports/U.S. Indus try Size). U. S. Indus try Size is defined as the 1997-2006 average value of U.S. shipments plus world imports. Also "Net imports LWC" is normalized by U.S. industry size. "Ch.\% LWC Manufacturing Output"is the weighted average growth rate of manufactu ring output in the nin e LWCs. The instrument employed is the labor intensity times Ch. \% LWC manufacturing output. All estimations include fixed effects by sector and year dummies; * si gn ificant at $5 \%$;* significan tat $1 \%$ 


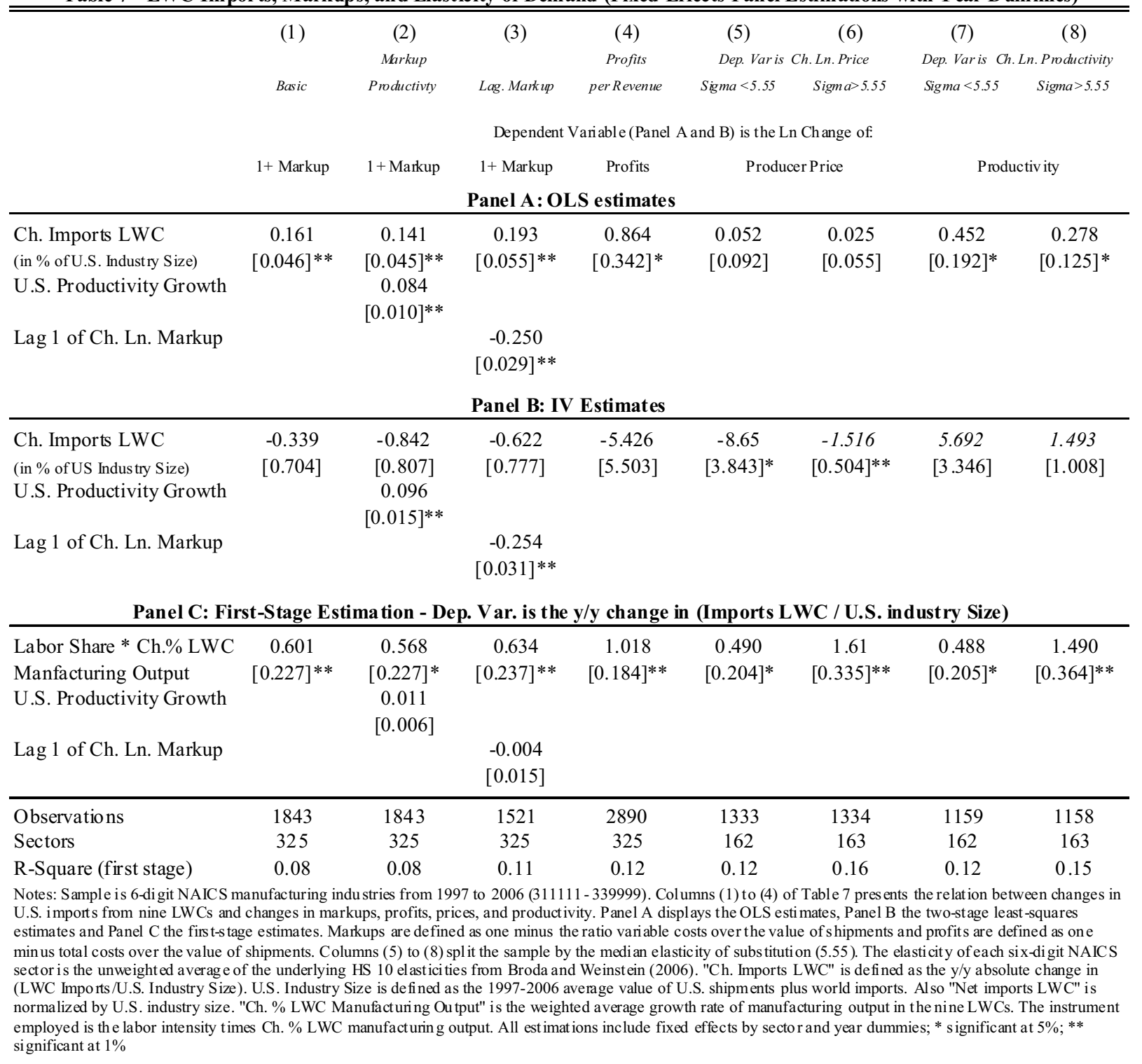



(1)
(2)
(3)
(4)
(5)
(6)
(7)
(8)
(9)
(10)
Lag1 Lags 1-2 Lags 1-3 Sigma $<5.55 \quad$ Sigma $>5.55 \quad$ (6) - (8) all sectors $\quad$ Sigma $<5.55$ Sigma $>5.55$

Panel A: First-Stage Estimation - Dependent Variable is the y/y change of Imports LWC / US industry Size

\begin{tabular}{lccccc}
\multicolumn{5}{c}{ Panel A: First-Stage Estimation - Dependent Variable is the y/y ch } \\
\hline Labor Share * Ch. & 1.006 & 1.091 & 1.100 & 0.671 & 1.487 \\
\% LWC Manfct. Output & {$[0.184]^{* *}$} & {$[0.206]^{* *}$} & {$[0.226]^{* *}$} & {$[0.259]^{* *}$} & {$[0.363]^{* *}$} \\
Lag 1 Labor Share * Ch. & 0.287 & 0.262 & 0.167 & -0.227 & 0.537 \\
\% LWC Manfct. Output & {$[0.177]$} & {$[0.189]$} & {$[0.235]$} & {$[0.266]$} & {$[0.383]$} \\
Lag 2 Labor Share* Ch. & 0.351 & 0.411 & 0.161 & 0.612 \\
\% LWC Manfct. Output & {$[0.176]^{*}$} & {$[0.200]^{*}$} & {$[0.232]$} & {$[0.320]$} \\
Lag 3 Labor Share * Ch. & & -0.053 & -0.326 & 0.207 \\
\% LWC Manfct. Output & & {$[0.238]$} & {$[0.274]$} & {$[0.382]$}
\end{tabular}

Panel B: Reduced Form Estimates - Dependent Variable is the y/y Change of Ln U.S. Price PPI

Labor Share* Ch.

$\%$ LWC Manfct. Output

$\begin{array}{lll}-2.452 & -2.525 & -2.489\end{array}$

Lag 1 Labor Share * Ch.

$[0.504]^{* *} \quad[0.495]^{* *}\left[\begin{array}{lllr}0.544 & * * & -2.671 & -2.297 \\ 0.805\end{array}\right]^{* *} \quad[0.734]^{* *}$

$\%$ LWC Manfct. Output

$\begin{array}{lllll}-0.124 & 0.389 & -0.192 & 0.477 & -0.858\end{array}$

Lag 2 Labor Share * Ch.

$\left[\begin{array}{lllll}0.472 & {[0.511]} & {[0.572]} & {[0.844]} & {[0.779]}\end{array}\right.$

$\%$ LWC Manfct. Output

Lag 3 Labor Share* $\mathrm{Ch}$.

$\%$ LWC Manfct. Output

Lag 1 Ch. PPI Price

$\begin{array}{llll}-0.363 & -0.102 & -0.295 & 0.111\end{array}$

$[0.470] \quad[0.527] \quad[0.787] \quad[0.706]$

$\begin{array}{lll}-1.768 & -3.027 & -0.742\end{array}$

$[0.661]^{* *}[0.995]^{* *} \quad[0.890]$

Lag 1 Ch. PPI Price

$\begin{array}{lllll}-0.026 & -0.058 & -0.088 & -0.08 & -0.095\end{array}$

Lag 2 Ch. PPI Price

$[0.018] \quad[0.019]^{* *}[0.022]^{* *}[0.032]^{*} \quad[0.030]^{* *}$

Lag 3 Ch. PPI Price

$\begin{array}{llll}-0.112 & -0.139 & -0.109 & -0.157\end{array}$

$[0.019]^{* *}\left[\begin{array}{llll}0.022 & ]^{* *} & {[0.033}\end{array}\right]^{* *}\left[\begin{array}{ll}0.029 & ]^{* *}\end{array}\right.$

$\begin{array}{lll}-0.03 & -0.041 \quad-0.033\end{array}$

$[0.023] \quad[0.035] \quad[0.031]$

\begin{tabular}{cccccccccccc} 
Year dummies & $\mathrm{y}$ & $\mathrm{y}$ & $\mathrm{y}$ & $\mathrm{y}$ & $\mathrm{y}$ & $\mathrm{y}$ & $\mathrm{y}$ & $\mathrm{y}$ & $\mathrm{y}$ & & \\
\hline Observations & 2890 & 2568 & 2245 & 1129 & 1116 & 2345 & 2021 & 1700 & 851 & 849 \\
Sectors & 325 & 325 & 325 & 163 & 162 & 325 & 325 & 289 & 146 & 143 \\
R-Square (within) & 0.12 & 0.14 & 0.14 & 0.17 & 0.14 & - & - & -
\end{tabular}

Notes: Sa mple is 6-digit NAICS manufacturing industries from 1997 to 2006 (311111-339999). Table 8 displays the long-run effect of LWC trade on LWC imports and U.S. prices. Panel A presents the first-stage estimation relating LWC output growth to LWC imports and Panel B presents the results re a ting imports or growth in LWCs to U.S. pric es. In Panel A Columns (1) to (5), the estimat ion a dds lagged values of the interaction of LWC growth and labor intensity directly to prices. Columns (5) to (10) display reduced-form estimations that rela te the (hgged) interac tion of LWC gr owth and labor intensity directly to pric es. Columns (4), (5), (9), a nd (10) split the sample by the median elasticity of substitution (5.55). Ela sticities are from Broda and Weinstein (2006). "Ch. Imports LWC" is de fined as the y/y absolute change in (LWC Imports/U.S. Industry Size). U.S. Industry Size is defined as the 1997-2006 average va lue of U.S. shipments plus world imports. Also "N et imports LWC" is normalized by U.S. industry size. "Ch. \% LWC Manufac turing Output" is the weighted average growt h rate of manufacturing output in the nine LWCs. The instrument employed is the labor intensity times $\mathrm{Ch}$. \% LWC manufacturing output. All estimations include fixed effects by sector and year dummi es; ${ }^{*}$ significant at $5 \%$; ${ }^{*}$ signific ant at $1 \%$ 
Figure 1: Share of Low-Wage Country Imports 1989 to 2006

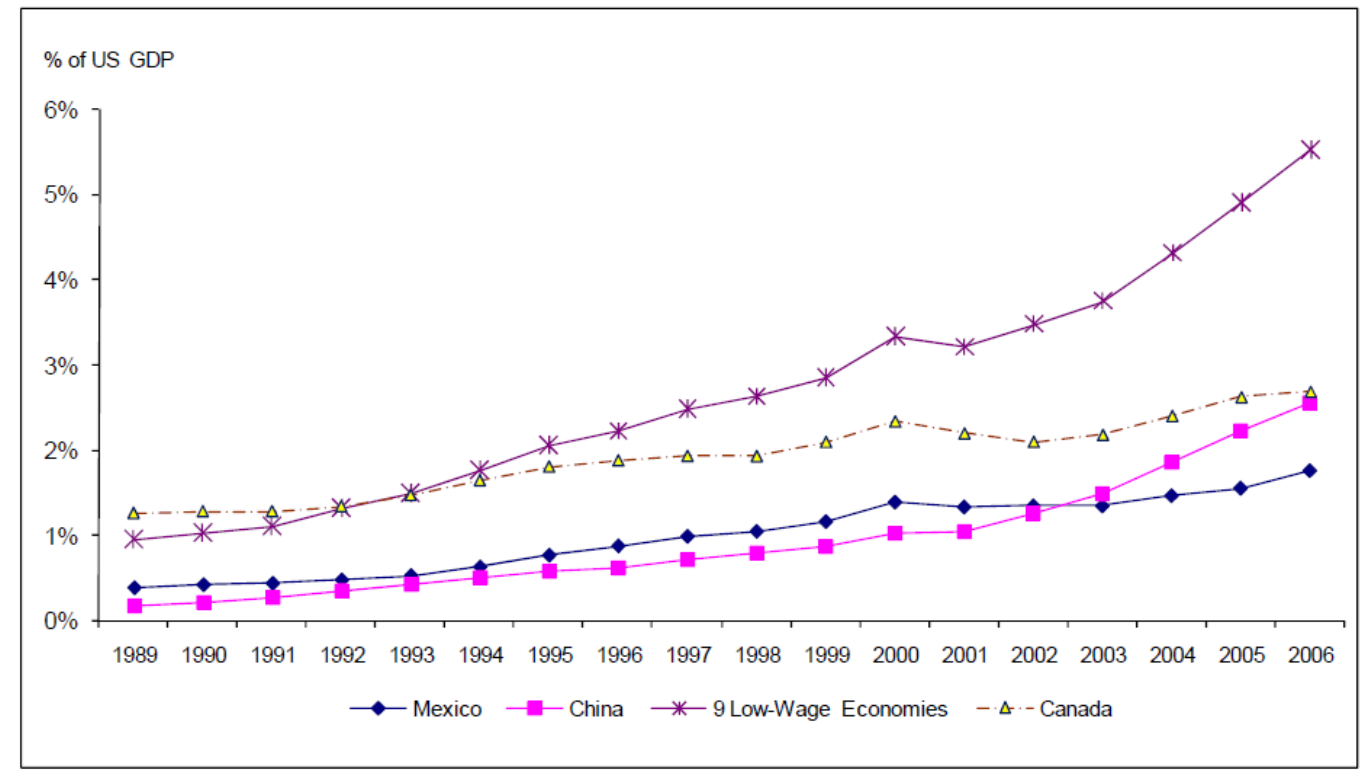

Notes: Source is United States International Trade Commission. 
Figure 2


Notes: Labor intensity is defined as the ratio of the 1997 to 2006 average of labor expenditures over labor plus capital expenditures. Labor share is from the U.S. Annual Survey of Manufacturers and is defined as total compensation of employees divided by total compensation of employees and total capital expenditures. 
Figure 3: Average Labor Intensity of U.S. Imports

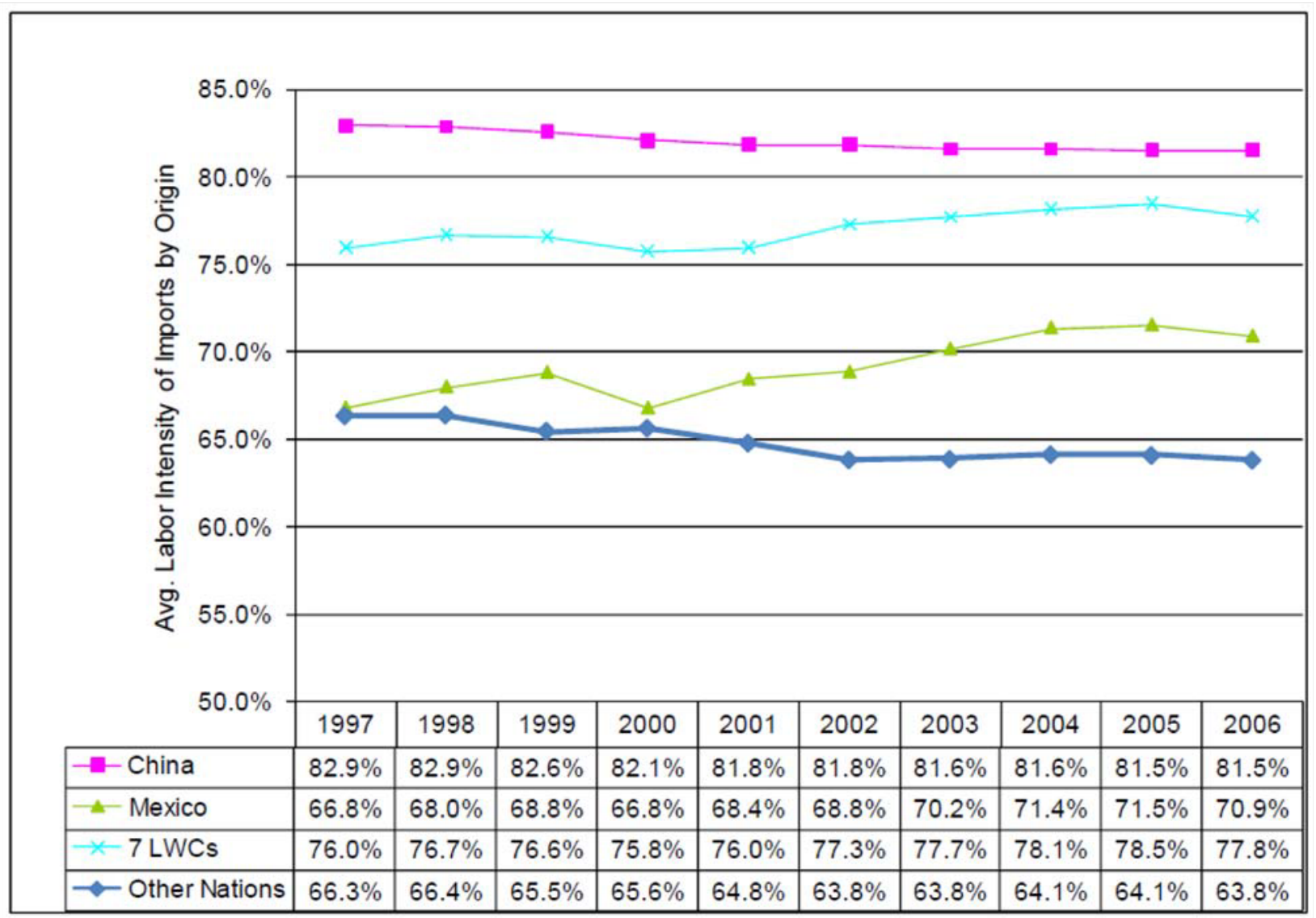

Notes: The seven low-wage countries are Brazil, India, Indonesia, Malaysia, the Philippines, Thailand, and Vietnam. Labor intensity is defined as the ratio of the 1997 to 2006 average of labor expenditures over labor plus capital expenditures. Labor share is from the U.S. Annual Survey of Manufacturers and is defined as total compensation of employees divided by total compensation of employees and total capital expenditures. 
Figure 4: Factor Supply in China 1996 to 2004

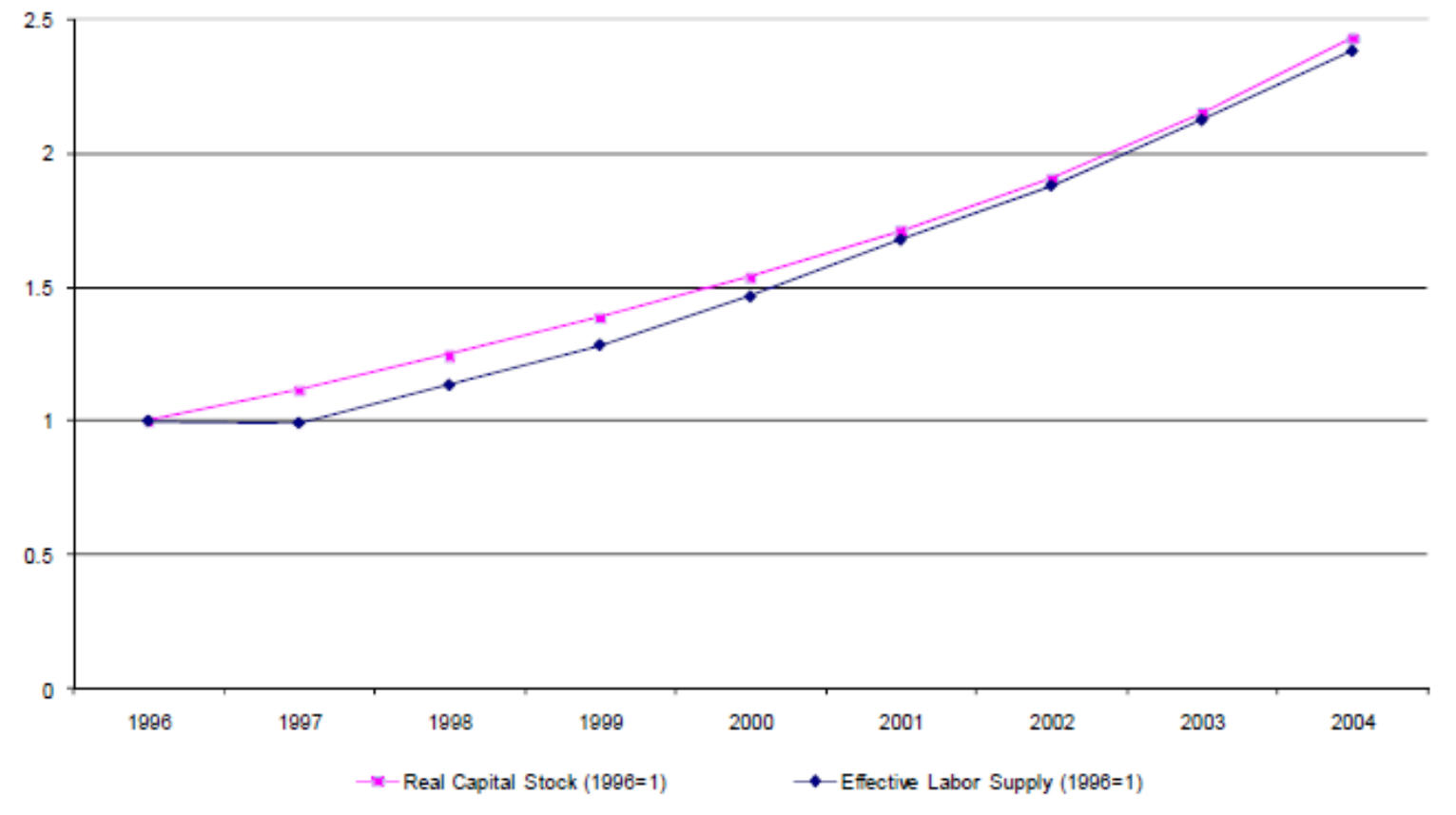

Notes: Real capital stock is from B. Bosworth used in Bosworth and Collins (2007). Effective labor supply equals the total number of persons employed in China (Asian Development Bank) times real manufacturing wage growth in China (nominal wage growth from Laborstat database ILO and GDP deflator from the World Bank Development Indicators). 


\section{Swiss National Bank Working Papers published since 2004:}

2004-1 Samuel Reynard: Financial Market Participation and the Apparent Instability of Money Demand

2004-2 Urs W. Birchler and Diana Hancock: What Does the Yield on Subordinated Bank Debt Measure?

2005-1 Hasan Bakhshi, Hashmat Khan and Barbara Rudolf: The Phillips curve under state-dependent pricing

2005-2 Andreas M. Fischer: On the Inadequacy of Newswire Reports for Empirical Research on Foreign Exchange Interventions

2006-1 Andreas M. Fischer: Measuring Income Elasticity for Swiss Money Demand: What do the Cantons say about Financial Innovation?

2006-2 Charlotte Christiansen and Angelo Ranaldo: Realized Bond-Stock Correlation: Macroeconomic Announcement Effects

2006-3 Martin Brown and Christian Zehnder: Credit Reporting, Relationship Banking, and Loan Repayment

2006-4 Hansjörg Lehmann and Michael Manz: The Exposure of Swiss Banks to Macroeconomic Shocks - an Empirical Investigation

2006-5 Katrin Assenmacher-Wesche and Stefan Gerlach: Money Growth, Output Gaps and Inflation at Low and High Frequency: Spectral Estimates for Switzerland

2006-6 Marlene Amstad and Andreas M. Fischer: Time-Varying Pass-Through from Import Prices to Consumer Prices: Evidence from an Event Study with Real-Time Data

2006-7 Samuel Reynard: Money and the Great Disinflation

2006-8 Urs W. Birchler and Matteo Facchinetti: Can bank supervisors rely on market data? A critical assessment from a Swiss perspective

2006-9 Petra Gerlach-Kristen: A Two-Pillar Phillips Curve for Switzerland

2006-10 Kevin J. Fox and Mathias Zurlinden: On Understanding Sources of Growth and Output Gaps for Switzerland

2006-11 Angelo Ranaldo: Intraday Market Dynamics Around Public Information Arrivals

2007-1 Andreas M. Fischer, Gulzina Isakova and Ulan Termechikov: Do FX traders in Bishkek have similar perceptions to their London colleagues? Survey evidence of market practitioners' views 
2007-2 Ibrahim Chowdhury and Andreas Schabert: Federal Reserve Policy viewed through a Money Supply Lens

2007-3 Angelo Ranaldo: Segmentation and Time-of-Day Patterns in Foreign Exchange Markets

2007-4 Jürg M. Blum: Why `Basel II’ May Need a Leverage Ratio Restriction

2007-5 Samuel Reynard: Maintaining Low Inflation: Money, Interest Rates, and Policy Stance

2007-6 Rina Rosenblatt-Wisch: Loss Aversion in Aggregate Macroeconomic Time Series

2007-7 Martin Brown, Maria Rueda Maurer, Tamara Pak and Nurlanbek Tynaev: Banking Sector Reform and Interest Rates in Transition Economies: Bank-Level Evidence from Kyrgyzstan

2007-8 Hans-Jürg Büttler: An Orthogonal Polynomial Approach to Estimate the Term Structure of Interest Rates

2007-9 Raphael Auer: The Colonial Origins Of Comparative Development: Comment. A Solution to the Settler Mortality Debate

2007-10 Franziska Bignasca and Enzo Rossi: Applying the Hirose-Kamada filter to Swiss data: Output gap and exchange rate pass-through estimates

2007-11 Angelo Ranaldo and Enzo Rossi: The reaction of asset markets to Swiss National Bank communication

2007-12 Lukas Burkhard and Andreas M. Fischer: Communicating Policy Options at the Zero Bound

2007-13 Katrin Assenmacher-Wesche, Stefan Gerlach, and Toshitaka Sekine: Monetary Factors and Inflation in Japan

2007-14 Jean-Marc Natal and Nicolas Stoffels: Globalization, markups and the natural rate of interest

2007-15 Martin Brown, Tullio Jappelli and Marco Pagano: Information Sharing and Credit: Firm-Level Evidence from Transition Countries

2007-16 Andreas M. Fischer, Matthias Lutz and Manuel Wälti: Who Prices Locally? Survey Evidence of Swiss Exporters

2007-17 Angelo Ranaldo and Paul Söderlind: Safe Haven Currencies 
2008-1 Martin Brown and Christian Zehnder: The Emergence of Information Sharing in Credit Markets

2008-2 Yvan Lengwiler and Carlos Lenz: Intelligible Factors for the Yield Curve

2008-3 Katrin Assenmacher-Wesche and M. Hashem Pesaran: Forecasting the Swiss Economy Using VECX* Models: An Exercise in Forecast Combination Across Models and Observation Windows

2008-4 Maria Clara Rueda Maurer: Foreign bank entry, institutional development and credit access: firm-level evidence from 22 transition countries

2008-5 Marlene Amstad and Andreas M. Fischer: Are Weekly Inflation Forecasts Informative?

2008-6 Raphael Auer and Thomas Chaney: Cost Pass Through in a Competitive Model of Pricing-to-Market

2008-7 Martin Brown, Armin Falk and Ernst Fehr: Competition and Relational Contracts: The Role of Unemployment as a Disciplinary Device

2008-8 Raphael Auer: The Colonial and Geographic Origins of Comparative Development

2008-9 Andreas M. Fischer and Angelo Ranaldo: Does FOMC News Increase Global FX Trading?

2008-10 Charlotte Christiansen and Angelo Ranaldo: Extreme Coexceedances in New EU Member States' Stock Markets

2008-11 Barbara Rudolf and Mathias Zurlinden: Measuring capital stocks and capital services in Switzerland

2008-12 Philip Sauré: How to Use Industrial Policy to Sustain Trade Agreements

2008-13 Thomas Bolli and Mathias Zurlinden: Measuring growth of labour quality and the quality-adjusted unemployment rate in Switzerland

2008-14 Samuel Reynard: What Drives the Swiss Franc?

2008-15 Daniel Kaufmann: Price-Setting Behaviour in Switzerland - Evidence from CPI Micro Data

2008-16 Katrin Assenmacher-Wesche and Stefan Gerlach: Financial Structure and the Impact of Monetary Policy on Asset Prices

2008-17 Ernst Fehr, Martin Brown and Christian Zehnder: On Reputation: A Microfoundation of Contract Enforcement and Price Rigidity 
2008-18 Raphael Auer and Andreas M. Fischer: The Effect of Low-Wage Import Competition on U.S. Inflationary Pressure 
Swiss National Bank Working Papers are also available at www.snb.ch, section Publications/Research Subscriptions or individual issues can be ordered at Swiss National Bank, Fraumünsterstrasse 8, CH-8022 Zurich, fax+41 4463181 14, E-mail library@snb.ch 